FEDERAL RESERVE BANK OF SAN FRANCISCO

WORKING PAPER SERIES

\title{
Monetary and Financial Integration in the EMU: \\ Push or Pull?
}

Mark M. Spiegel

Federal Reserve Bank of San Francisco

July 2008

Working Paper 2008-11

http://www.frbsf.org/publications/economics/papers/2008/wp08-11bk.pdf

The views in this paper are solely the responsibility of the author and should not be interpreted as reflecting the views of the Federal Reserve Bank of San Francisco or the Board of Governors of the Federal Reserve System. This paper was produced under the auspices of the Center for Pacific Basin Studies within the Economic Research Department of the Federal Reserve Bank of San Francisco. 


\title{
Monetary and Financial Integration in the EMU: Push or Pull?
}

\author{
Mark M. Spiegel ${ }^{*}$ \\ Federal Reserve Bank of San Francisco
}

July 15, 2008

\begin{abstract}
A number of studies have recently noted that monetary integration in the European Monetary Union (EMU) has been accompanied by increased financial integration. This paper examines the channels through which monetary union increased financial integration, using international panel data on bilateral international commercial bank claims from 1998-2006. I decompose the relative increase in bilateral commercial bank claims among union members following monetary integration into three possible channels: A "borrower effect," as a country's EMU membership may leave its borrowers more creditworthy in the eyes of foreign lenders; a "creditor effect," as membership in a monetary union may increase the attractiveness of a nation's commercial banks as intermediaries, perhaps through increased scale economies enjoyed by commercial banks themselves or through an improved regulatory environment after the advent of monetary union; and a "pairwise effect," as joint membership in a monetary union increases the quality of intermediation between borrowers and creditors when both are in the same union. This pairwise effect could be attributed to mitigated currency risk stemming from monetary integration, but may also indicate that monetary union integration increases borrowing capacity. I decompose the data into a series of difference-in-differences specifications to isolate these three channels and find that the pairwise effect is the primary source of increased financial integration. This result is robust to a number of sensitivity exercises used to address concerns frequently associated with difference-in-differences specifications, such as serial correlation and issues associated with the timing of the intervention.
\end{abstract}

JEL classification: F15, F33, F34

Key words: euro, EMU, monetary union, bank lending, financial diversion

${ }^{*}$ Mark.Spiegel@sf.frb.org. Federal Reserve Bank of San Francisco, 101 Market St., San Francisco, CA, 94105 Helpful comments were received from Joshua Aizenman, Galina Hale, Michael Hutchison, Oscar Jorda, Ilan Noy, Clas Wihlborg, and participants at the 2008 RIE-SCCIE Global Liquidity Conference. Christopher Candelaria provided excellent research assistance. All views presented in this paper are those of authors and do not represent the views of the Federal Reserve Bank of San Francisco or Federal Reserve Board of Governors. 


\section{Introduction}

The advent of the European Monetary Union (EMU) in 1999 resulted in a large increase in the current account deficits of EMU borrower nations, such as Portugal and Greece. By the year 2000, Portugal had reached a current account deficit equal to about 10 percent of its GDP, while Greece, which was on the road to EMU accession itself, reached a current account deficit between 6 and 7 percent of GDP. These current account deficits had been at levels around 2-3 and 1-2 percent of GDP respectively at the start of the decade [Blanchard and Giavazzi (2002)]. Studies of the accession experience have shown that in addition to leading to increases in overall borrowing, the advent of the EMU appears to have led to increased financial integration within the union itself, a phenomenon known as the "euro effect." It therefore appears that this increased financial integration facilitated the increased net borrowing conducted by Portugal and Greece subsequent to their EMU accession.

While early evidence of a euro effect on financial integration was mixed [e.g. Adam, Japelli, Menichini, Padula, and Pagano (2002) and Blanchard and Giavazzi (2002)], more recent studies [e.g. Lane (2006a) and (2006b)] have found evidence of a substantial increase in financial integration subsequent to the launch of the euro. One could envision three alternative sources for this widely

observed euro effect: First, there may be a "borrower effect," as a country's EMU membership may leave its borrowers more creditworthy in the eyes of foreign lenders. This might be because membership in the European Union brought formal borrowing constraints, such as the Growth and Stability Pact that limited fiscal deficits, or informal constraints, such as a perceived increase in the penalty for default on lending (e.g. Gourinchas and Jeanne (2006)), that would reduce the perceived probability of default risk among union members at any given debt level.

Alternatively, the increase could represent a creditor effect, as membership in a monetary union may increase the attractiveness of a nation's commercial banks as intermediaries, perhaps through increased scale economies enjoyed by commercial banks themselves or through an improved 
regulatory environment after the advent of monetary union.

Finally, the increase could represent a "pairwise" effect, as joint membership in a monetary union increases the quality of intermediation between borrowers and creditors when both are in the same union. This pairwise effect could be attributed to mitigated currency risk stemming from monetary integration, but may also indicate that monetary union integration encourages cooperative behavior between private agents in union member countries or disproportionately increase the perceived penalty for default on fellow union members.

This paper examines these alternative components of the euro effect to determine which played an important role in the observed overall increased financial integration within the monetary union. I examine the impact of the advent of the euro on international commercial bank lending using the BIS bilateral data on international commercial bank claims. I first introduce a difference-indifferences specification that incorporates all three of the potential channels for the euro to lead to increased financial integration in the context of a gravity model of lending. Portes and Rey (2005) demonstrate that gravity model of portfolio movements explains a larger share of variability in the data than the gravity model of trade. Rose and Spiegel (2004) demonstrate that the gravity model explains well the variability in the BIS commercial bank data used in this study.

However, the bilateral nature of lending data does not lend itself readily to a difference-indifferences study, as the advent of the euro simultaneously "treats" EMU-member creditors as well as EMU member debtors. As such, a specification that merely looks at bilateral flows would be incapable of separating out the three possible channels of increase financial integration discussed above. Indeed, our results from observing the full sample suggests no "euro effect" after conditioning for country distance. This result would be surprising in light of the substantial evidence that financial integration increased after the advent of the euro for a variety of forms of financial flows.

To examine the independent effects of the advent of the euro, I examine sub-samples that isolate the components of the euro-effect. For example, a proper difference-in-differences test of 
the pairwise effect can be conducted by examining the impact of the euro on the set of loans between EMU creditors and debtors and the "control group" of non-EMU creditor lending to nonEMU borrowers. Similarly, the borrower effect can be isolated by comparing borrowing from both EMU and non-EMU borrowers from the sets of EMU and non-EMU creditors separately. The intuition is that if a borrower channel existed alone, it should make the EMU borrower countries better borrowers from both EMU creditors and non-EMU creditors. Finally, we isolate the creditor effect similarly, by comparing lending by EMU and non-EMU creditors to the groups of EMU and non-EMU borrowers separately.

Our results suggest that there is a euro effect for bilateral commercial bank lending and that it corresponds to a pairwise effect. As such, our analysis supports the contention that the euro effect is either attributable to reduced currency risk of lending between euro member nations or disproportionately increased default risk on borrowing from EMU partner member nations. These results are robust to a number of sensitivity tests, including choosing earlier dates for the timing of "monetary integration," and treating pre- and post-integration data as single observations to account for possible serial correlation in the data.

The remainder of this paper is divided into six sections. Section 2 reviews the literature on the financial integration impact of the EMU. Section 3 introduces our empirical specifications. Section 4 discusses our data set and provides descriptive statistics. Section 5 discusses our empirical results and Section 6 presents some evidence concerning the robustness of our results. Finally, Section 7 concludes.

\section{Previous Literature}

There appears to be a general consensus that the advent of the euro corresponded to increased financial integration within the euro area. Blanchard and Giavazzi (2002) show that increases in 
the 1990s of the correlations between current account positions and per capita incomes of future European Monetary Union (EMU) countries exceeded those of non-EMU European Union (EU) countries, and further exceeded those of non-EU OECD countries. There are a number of reasons why monetary integration might enhance financial integration: First, monetary integration reduces currency risk in international lending between partner countries. Second, membership in a monetary union increases the penalty for default on lending (Gourinchas and Jeanne, 2006). Moreover, Blanchard and Giavazzi (2002) argue that the results in Rose (2000) suggest that monetary union also facilitates inter-temporal trade by allowing nations to run larger positive or negative current account balances. They describe the large increase in borrowing by new partner nations as a "natural" outcome of increased international integration, as capital flows more freely as a result of the integration from rich to poor countries.

However, the pace of increase in integration appears to be mixed. On one hand, there appears to be considerable evidence of decreased interest rate differentials and increased volumes of crossborder issues in European bond and money markets, as in Adam, Japelli, Menichini, Padula, and Pagano (2002), Hartmann, Manna, and Manzanares (2001), Galati and Tsatsaronis (2003), Pagano and Von Thadden (2004), Baele, Ferrando, Hördahl, Krylova, and Monnet (2004), and Santos and Tsatsaronis (2006). Baele, Ferrando, Hördahl, Krylova, and Monnet (2004) find a considerable drop in the dispersion of unsecured overnight rates in European money markets in January 1999, although some residual dispersion persists. Longer-term unsecured lending rates also converged dramatically after the advent of the euro. Coeurdacier and Martin (2006) find that the advent of the euro has resulted in an increase of the elasticity of substitution between bonds inside the euro zone.

On the other hand, for less standardized credit markets, the results appear to be more mixed. Looking at interest rate differentials, Adam, Japelli, Menichini, Padula, and Pagano (2002) find substantial disparities for mortgages and short-term loans. They do find a substantial acceleration 
in the pace of convergence in interest rates for mortgage loans in the run-up to the launch of the euro, but only weak evidence for convergence in the corporate loan market. They stress the low presence of foreign banks in the euro area as evidence of this low level of financial integration. Cabral, Dierick, and Vesala (2002) also find that financial integration in retail banking proceeded slowly after the launch of the euro, although they find substantial evidence of financial integration in other banking services, such as bond underwriting. Baele, Ferrando, Hördahl, Krylova, and Monnet (2004) find substantial convergence in mortgage loan rates subsequent to the launch of the euro, although the consumer credit market appears to have remained highly segmented. A number of factors have been identified in the literature for the slower pace of international convergence in the banking sector.

Still, as stressed by Japelli and Pagano (2008), measures of financial integration based on price similarities may be misleading, as financial integration may result in increased shares of intermediation serviced by foreign banks 11 As such, changes in the volume of cross-border lending is a viable alternative measure of financial integration. Evidence for increased volumes of crossholdings of bonds in the euro area around the time of the launch of the euro has been shown by Baele, Ferrando, Hördahl, Krylova, and Monnet (2004) and a number of studies by Lane [Lane (2006a), Lane (2006b)]. Hale and Spiegel (2008) using firm-level data find that the Euro led to substitution in bond markets towards euro-denominated issues from other popular international currencies, such as the U.S. dollar, as well as smaller outsider country currencies. Spiegel (2008) finds evidence of a euro-area bias among Portuguese and Greek commercial bank borrowers subsequent to EMU accession using the BIS data examined in the current paper. The contention that this increase in borrowing volume is associated with increased financial integration among euro area countries is supported by Sørensen and Gutiérrez (2006), who demonstrate using cluster techniques that Greece and Portuguese banking sectors became more similar to their euro-area counterparts over

\footnotetext{
${ }^{1}$ Ironically, this may result in increased disparities in lending terms, as markets become more segmented and domestic banks specialize in servicing more complicated loans that require monitoring services difficult for foreign banks to provide at a distance.
} 
the period of their accession.

\section{Empirical specification}

The full sample consists of $I$ creditor nations, indexed by $i=1, \ldots, I$, , and $J$ debtor nations, indexed by $j=1, \ldots, J$, observed over $T$ periods, $t=1, \ldots, T$. I number the creditors such that creditors 1 through $i^{*}$ join the monetary union and creditors $i^{*+1}$ through $I$ do not. Similarly, I number the borrowers such that borrowers 1 through $j^{*}$ join the monetary union, while borrowers $j^{*+1}$ through $J$ do not. Let $L_{i j t}$ represent the $\log$ of country $i$ lending to country $j$ at time $t$.

Most previous difference-in-differences panel studies of the euro effect contrast some sample of lending volumes between a pairs of debtors and creditor countries that joined the EMU and some control group. for example, let $E M U_{i j t}^{\text {pair }}=1$ if creditor country $i$ and debtor country $j$ are both in the monetary union at time $t$, and 0 otherwise. Spiegel (2008) estimates the following equation,

$$
L_{i j t}=c+\phi_{t}+\theta_{i}+\gamma_{j}+\beta_{1} E M U_{i j t}^{p a i r}+\delta X_{i j t}+\varepsilon_{i j t}
$$

where $\phi_{t}, \theta_{i}$, and $\gamma_{j}$ are time and creditor and debtor country fixed effects respectively, $X_{i j t}$ is a vector of other conditioning variables described below, including the distance variable associated with the gravity specification, and $\varepsilon_{i j t}$ is assumed to be an i.i.d. disturbance term. The sample used in Spiegel (2008) consists of a panel of bilateral lending from a group of EMU and non-EMU creditor countries towards two debtor countries that joined the EMU, Portugal and Greece. The variable of interest in equation 1 ,,$E M U_{i j t}^{\text {pair }}$, is equal to 0 for all observations for lending to Portugal and Greece by non-EMU creditors and by EMU-country creditors prior to accession, and 1 for lending by EMU-country creditors after accession. The paper interprets a significant positive coefficient on $E M U_{i j t}^{\text {pair }}$ as evidence of a "euro effect" on financial integration.

However, as discussed above, the advent of the euro could have had three distinct impacts on 
the pattern of international lending, a pairwise effect, a pure creditor effect, and a pure borrower effect. One can consider $E M U_{i j t}^{\text {pair }}$ as a measure of the aforementioned pairwise effect. Similarly, one could identify a pure creditor effect, $E M U_{i t}^{\text {cred }}=1$, via an intervention variable that is equal to 1 if creditor country $i$ is in the monetary union at time $t$, and 0 otherwise, and a pure borrower effect, $E M U_{j t}^{\text {borr }}=1$, via an intervention variable that is equal to 1 if borrower country $j$ is in the monetary union at time $t$, and 0 otherwise.

Using this notation, it can be seen that the $E M U_{i j t}^{\text {pair }}$ variable in the specification above could be interpreted either as a pairwise effect or as a pure creditor effect. To isolate the three possible channels of the euro effect, I consider the following specification

$$
L_{i j t}=c+\phi_{t}+\theta_{i}+\gamma_{j}+\beta_{1} E M U_{i j t}^{p a i r}+\beta_{2} E M U_{i t}^{c r e d}+\beta_{3} E M U_{j t}^{b o r r}+\delta X_{i j t}+\varepsilon_{i j t},
$$

where the variables are as described above, and our sample panel includes both borrower countries that both did and did not join the EMU.

It can immediately be seen that equation (2) does not represent a standard difference-indifferences specification, as we are simultaneously conditioning for three treatment effects. While we would expect our specification to be consistent, there may be difficulty identifying the individual channels through which the euro effect increases financial integration because these variables are likely to be highly collinear. Indeed, in the sample described below the correlation between $E M U_{i j t}^{\text {pair }}$ and $E M U_{j t}^{\text {borr }}$ variables is equal to 0.70, while the correlation between $E M U_{i j t}^{\text {pair }}$ and $E M U_{i t}^{\text {cred }}$ is equal to 0.302 This makes it quite likely that we would have difficulty isolating the individual pairwise and borrower effects, and raises some concerns about our ability to isolate the creditor effects as well.

In response, we also examine sub-samples that isolate the individual EMU effects. For example,

${ }^{2}$ The correlation between $E M U_{j t}^{\text {borr }}$ and $E M U_{i t}^{\text {cred }}$ is only equal to 0.17 . 
consider the following specification as a test for the pairwise effect of the advent of the euro

$$
L_{i j t}=c+\phi_{t}+\theta_{i}+\gamma_{j}+\beta_{1} E M U_{i j t}^{p a i r}+\delta X_{i j t}+\varepsilon_{i j t}
$$

where our sub-sample includes the observations that received the pair treatment effect, i.e. bilateral lending between pairs of creditor and debtor countries that both eventually entered the EMU, and the observations that correspond to pairs that received no treatment effect, i.e. bilateral lending between pairs of creditor and debtor countries where neither eventually enter the EMU. This specification picks up the pure "pairwise effect," and is uncontaminated by the debtor or creditor effects.

Similarly, consider the following specification as a test for the creditor effect of the advent of the euro

$$
L_{i j t}=c+\phi_{t}+\theta_{i}+\gamma_{j}+\beta_{1} E M U_{i t}^{c r e d}+\delta X_{i j t}+\varepsilon_{i j t}
$$

where our sub-sample includes all of the observations for lending to borrowers who did not enter the EMU. This sub-sample captures the pure "creditor effect," as if entering the EMU made a country a more desirable creditor, it should have that effect on lending to non-EMU members as well as EMU members.

Finally, consider the following specification as a test for the borrower effect on the advent of the euro

$$
L_{i j t}=c+\phi_{t}+\theta_{i}+\gamma_{j}+\beta_{1} E M U_{i t}^{b o r r}+\delta X_{i j t}+\varepsilon_{i j t}
$$

where our sub-sample includes all of the observations for lending to borrowers who did not enter the EMU. This sub-sample captures the pure "borrower effect," as if entering the EMU made a country a more desirable borrower, it should have that effect on borrowing from non-EMU members as well as EMU members.

Our methodology is therefore to estimate the panel specifications above with their appropriate 
samples to identify the channels through which the euro effect occurred. I estimate panel specifications with borrower, creditor, and time fixed effect with robust standard errors and clustering by creditor country. I also conduct a number of robustness checks to address a variety of potential econometric concerns with this specification below.

\section{Data}

I use consolidated BIS data on total foreign claims of reporting banks for 16 creditor countries and 16 debtor countries from the second quarter of 1985 through the fourth quarter of 2006 . Foreign claims include cross-border claims and local claims of foreign affiliates in both local and foreign currency. Alternative measures of foreign exposure include cross-border or international claims. Cross-border claims miss direct foreign investment in the financial sector, while the international claims category, which includes cross-border claims plus local foreign-currency claims of foreign affiliates, misses local currency claims of foreign affiliates. In particular, this category would miss euro-denominated loans extended after EMU formation. In contrast, the total foreign claims measure in this paper incorporates all of these components of foreign exposure $3^{3}$

Data is semi-annual and is converted to 2000 real U.S. dollars, deflated by the consumer price index.4 Creditor countries with missing observations include Canada 1999 Q2; Denmark 1999 Q2, 2000 Q2, 2000 Q4; Italy 2001 Q4; and Norway 1999 Q2. Norway also had missing data from 1985 Q4 to 1993 Q4. Many of the bilateral claims are reported to be zero. This leaves the $\log$ transformation potentially influential and questionable. I therefore examine the robustness of the results to avoiding this transformation below.

\footnotetext{
3 The consolidated BIS figures may induce errors in measurement of cross-border obligations from a number of sources: First, the use of consolidated data may not correctly assign the risk of banks' foreign-branches. Second, "outward risk transfers" are sometimes used to transfer risks to residents of other countries, and this data set would not pick these up. Still, as these errors fall in the regressand of the specification they only make the effect of EMU accession harder to find and do not appear to introduce any bias issues.

${ }^{4}$ Data are for second and fourth quarters. Data is available quarterly beginning in 1999, but cannot be used for a difference-in-differences exercise at that frequency as the intervention also occurred in 1999.
} 
BIS data is available for 20 creditor countries, but the inclusion of conditioning variables reduces our sample of creditor countries to sixteen. The creditor countries in the sample include Austria, Belgium, Canada, Denmark, Finland, France, Germany, Italy, Japan, Netherlands, Norway, Spain, Sweden, Switzerland, United Kingdom, and the United States.

Our sample includes 16 debtor countries. Unfortunately, data on bilateral borrowing by the BIS creditor countries themselves was not released by the BIS prior to 1999. As the initial EMU partner nations tend to include prominent creditor countries, bilateral data is largely unavailable for these nations. For example, one cannot obtain commercial bank claims by the United Kingdom on France prior to 1999. As we are interested in assessing the impact of EMU accession in that year, no bilateral borrowing data is available for the bulk of EMU entrants. Fortunately, data are available for Portugal and Greece, as they are not BIS creditor countries. Bilateral claims on lending to those countries from all of the creditor nations in our sample are available semi-annually both before and after the launch of the EMU and Greece's subsequent accession, which allows for a difference-in-differences specification for borrower effects as well $5^{5}$

There might be some concern that our EMU borrowing nations may not be representative, particularly during the time of Europe's monetary integration. At that time, Portugal was a relatively new member of the European Union, having only entered in 1986. Moreover, the nation embarked on an extensive financial reform program in 1984, authorizing new private entry into the banking system, and eventually privatizing 11 of the 12 state-owned banks that had previously dominated the system [Canhoto and Dermine (2003)]. However, it is unclear why this financial liberalization would act in favor of relative increases in borrowing from EMU partner-nation banks. If anything, one would think that regulatory forces that might encourage borrowing from EMU partner nation banks would be mitigated by financial reforms.

In the case of Greece, one might be concerned that the country's increased borrowing capacity

\footnotetext{
${ }^{5}$ For more details on Portugal and Greece's accession to EMU, see Spiegel (2008).
} 
may stem from the substantial macroeconomic reforms in efforts it achieved to meet the Maastricht criteria for admission to the Union during the 1990s. Alternatively, there might be some concern that the increase observed in borrowing from EMU members might reflect a reduction in borrowing capacity during the period of disinflation prior to EMU accession. However, as in the Portuguese case, these factors appear relevant to overall borrowing capacity, rather than the relative volume of borrowing from EMU 6

The relatively small size of these economies may also be advantageous from an econometric point of view. A common misgiving with difference-in-differences tests is that the membership in the group experiencing the intervention is dependent on the anticipated benefits of the intervention [e.g. Besley and Case (2000)]. In this case, the analysis would be distorted if the decision by EMU creditor countries to join the monetary union was affected by anticipated increased integration with Portugal and Greece. However, since the quantity of international borrowing by these countries is small relative to lending by most of the euro-area creditor nations, that concern does not seem to be relevant here.

Our conditioning variables include $D I S T_{i j}$, the $\log$ of distance between creditor country $i$ and debtor country $j ; E C_{k}(k=i, j)$, a dummy variable that takes value 1 if country $k$ is a European Community member, and value 0 otherwise; $G D P_{k t}(k=i, j)$, the log of total real gross domestic product of country $k$ at time $t ; G D P_{k t}(k=i, j)$, the log of total real gross domestic product of country $k$ at time $t ; \operatorname{GDPCAP} P_{k t}(k=j, t)$, the log of total real gross domestic product per capita of country $k$ at time $t$; TRADE $E_{i j t}$, the log of trade volume between countries $i$ and $j$ at time $t$ in year 2000 dollars, FRENCHLAW $(k=i, j)$, a dummy variable that indicates if country $k$ is under French law, BORDER $R_{i j}$, a dummy that indicates if countries $i$ and $j$ share a border. COMLANG $i j$, a dummy that indicates if countries $i$ and $j$ share a com-

\footnotetext{
${ }^{6}$ Moreover, the disinflation from 1994 to the end of the decade was not accompanied by a decline in economic activity. Real GDP growth increased to 2.8 percent from 1994 through 1999, up from 1 percent during the 1991-1994 period [Papaspyrou (2004)]
} 
mon language, $L A N D L O C K E D_{k}$, a dummy that indicates if creditor country $i$ is landlocked, $I S L A N D_{k}(k=i, j)$, a dummy that indicates if country $k$ is an island, $A R E A_{k}(k=i, j)$, the $\log$ of land area of country $k, T A X H A V E N_{k}(k=i, j)$, a dummy indicating if country $k$ is a tax haven, GOVERNANCE $E_{k}(k=i, j)$, a measure of the lack of corruption in country $k$, and $O F C_{k}$ $(k=i, j)$, a dummy that indicates if country $k$ is an offshore financial center.

GDP data came primarily from the World Development Indicators 2006; these series were extended using data from the International Monetary Fund's International Financial Statistics. Trade data was obtained from the International Monetary Fund's Direction of Trade Statistics. Remaining dummy variables were obtained from Rose (2005), with the exception of $T A X H A V E N_{k}$, GOVERNANCE $E_{k}$, and $O F C_{k}$, which were obtained from Rose and Spiegel (2004).

Shares of bilateral borrowing by Greece and Portugal from EMU partner nations and others are shown in Table 1. The data suggests that bilateral borrowing by the EMU borrower nations in our sample moved away from non-European Community countries and towards the EMU-partner creditor nations in our sample. Borrowing from non-EC nations comprised $52.4 \%$ of overall borrowing by Portugal and $60.0 \%$ of Greek borrowing during the 1985-1991 period. Subsequent to accession to the EMU, that share fell to $5.8 \%$ for Portugal and $25.0 \%$ for Greece. In contrast, the share of borrowing from the EMU-partner nations in the sample more than doubled for both countries, increasing from $36.1 \%$ of overall borrowing in the initial period to $85.2 \%$ of overall borrowing for Portugal after 1999, and from 37.3\% in the initial period to $67.0 \%$ after 2001 for Greece. Borrowing from non-EMU EC countries fell modestly, from $11.4 \%$ of overall borrowing in the initial period for Portugal to $9.1 \%$ subsequent to EMU accession and from $11.6 \%$ to $8.1 \%$ in the case of Greece. Unsurprisingly, the bulk of borrowing from non-EMU EC countries comes from the United Kingdom.

These figures suggest that the brunt of the increased EMU-partner market share came at the expense of non-EC competitors, which could be considered a form of "financial diversion," analogous 
to the diversion of trade away from outsiders subsequent to the formation of trade unions. However, borrowing from non-EC countries only fell modestly for non-EC lending to Portugal, and more than doubled for non-EC lending to Greece. These increases corresponded to the huge current account deficits run by both of these countries subsequent to EMU accession, suggesting the possibility of a pure borrower effect associated with EMU accession.

Borrowing by the 14 non-EMU borrower nations in our sample is summarized in Table 2 . It can be seen that borrowing by the non-EMU nations also turned towards the EMU partner countries at the expense of borrowing from the non-EC countries. Borrowing from the non-EC countries fell from $59.3 \%$ of overall borrowing in the initial 1985-1991 period to $37.3 \%$ of total borrowing subsequent to the launch of the EMU in 1999. The benefactor of this change in market share was primarily the EMU creditor nations, whose market share rose from $27.2 \%$ in the initial period to $41.9 \%$ subsequent to the launch of the EMU. The substantial increase in market share in lending to non-EMU partner borrower nations by EMU creditor nations suggests the possibility of a pure creditor effect of the EMU as well. However, note that increased borrowing from the United Kingdom was also substantial. UK market share in lending to the non-EC borrower nation in our sample rose from $13.1 \%$ in the initial period to $20.6 \%$ after the launch of the EMU.

Overall, Tables 1 and 2 confirm the existence of a "euro effect," in the sense that borrowing from EMU creditors and by EMU debtors markedly increased after EMU accession. However, the raw data does not resolve whether this overall increase in lending activity is attributable to a "pairwise" EMU effect, or to pure debtor and creditor effects as well. To address that question, we next turn to our parametric results. 


\section{$5 \quad$ Results}

Results for estimation of equation (2) are shown in Table 3. Models 1 through 3 introduce the $E M U_{i j t}^{\text {pair }}, E M U_{i t}^{\text {cred }}$, and $E M U_{j t}^{\text {borr }}$ variables one at a time, and then without and with the conditioning variables in Models 4 and 5. It can be seen that we obtain positive coefficients on all of the EMU-accession variables, with the $E M U_{i j t}^{\text {pair }}$ and $E M U_{i t}^{\text {cred }}$ variables entering at statistically significant coefficient levels. To interpret the magnitude of these coefficients, consider that the average level of borrowing in an observation pair in our sample is equal to 19.0 in logs. An increase of 0.67 , our point estimate for the pairwise effect, would correspond to a predicted increase of borrowing from commercial banks in a random creditor country of approximately $\$ 170$ million. Similarly, a 0.37 increase in logs, the point estimate for the pure borrower effect, would correspond to a predicted increase of $\$ 80$ million. The 0.46 point estimate for the pure creditor effect, although it was statistically insignificant, would correspond to a predicted increase in borrowing from commercial banks in a random creditor country of $\$ 104$ million.

However, when we introduce all of the accession variables at the same time, as we argued above would be the specification needed to isolate the euro-effect channels in Models 4 and 5 they all enter insignificantly. this appears to confirm our fears above that one would have difficulty isolating the channels of the euro-effect in a specification using the full sample.

Turning to the conditioning variables, the $D I S T_{i j}$ variable enters robustly with its expected negative term. This supports the finding in the literature of a strong gravity effect for international bank lending [e.g. Rose and Spiegel (2004)]. The $E C_{i}$ variable was positive and significant in Model 4, suggesting the possibility of a European Community creditor effect. However, this variable is insignificant in the presence of the other conditioning variables. The $G D P C A P_{j t}$ variable is robustly negative, although the $G D P C A P_{j t}$ is robustly positive, suggesting that collinearity may be leading these two variables to eliminate each other in the data. We also obtain a robustly positive effect for bilateral trade levels, $T R A D E_{i j t}$, suggesting that borrowing may to some extent be 
taking place to finance bilateral trade. Among the other conditioning variables, we obtain robustly negative coefficients for $F R E N C H L A W_{j}, I S L A N D_{j}, O F C_{j}$, and robustly positive coefficients for $B O R D E R_{i j}$ and $A R E A_{j}$. Remaining conditioning variables are insignificant 7

Table 4 estimates equation (3) to examine the possibility of a pairwise euro effect in isolation. As discussed above, the sample includes pairs of countries with both EMU country borrowers and EMU country creditors and pairs of countries where neither borrowers nor creditors entered the EMU. Our results provide robust evidence of a pairwise euro effect. Our coefficient of interest enters positively at statistically significant confidence levels for all specifications, including Model 5 which is run in levels rather than logs. Moreover, our coefficient point estimates indicate a substantial pairwise effect. For example, Model 4 which includes all of our conditioning variables obtains a coefficient point estimate equal to 1.07 , which would predict an increase in borrowing from a random creditor country in our sample as a result of both the debtor country and the creditor country entering the EMU equal to $\$ 380$ million 8

Concerning our conditioning variables, we continue to obtain a significant negative point estimate on distance, at a $10 \%$ confidence level or more for all of our specifications, again supporting a gravity specification for bank lending. We also obtain positive and significant coefficient estimates on both $E C_{i}$ and $E C_{j}$ in Model 1, but these are not robust to the inclusion of the distance variable. As in the full sample, we obtain a negative and significant coefficient estimate on $G D P_{j t}$ and a positive and significant point estimate on $G D P C A P_{j t}$, as well as positive and significant point estimates on $T R A D E_{i j t}, B O R D E R_{i j}, I S L A N D_{j}$, and $O F C_{j}$. One distinction with the full sam-

\footnotetext{
${ }^{7}$ For space reasons, I suppressed the point estimates for some of the conditioning variables that were robustly insignificant. These include COMLANG $G_{i j}, L A N D L O C K E D_{i}, L A N D L O C K E D_{j}, T_{A X H A V E N}, T_{A X H A V E N}$, and all of the fixed effect coefficients. Point estimates for these coefficients are available on request.

${ }^{8}$ The size of the estimated EMU effect raises the possibility that other changes in the European financial environment also played a role in the increased observed volume of cross-border lending activity. In particular, CarboValverde, Kane, and Rodriguez-Fernandez (2008) note that a substantial amount of merger and acquisition activity took place over the same period in response to financial liberalization in the European Union. While I do condition for EU membership, this variable does not allow for time variation, and therefore would not capture the effect of financial liberalization in the EU over the course of the sample. This may result in an overestimation of the increase in financial integration attributable to the launch of the euro area. I thank the referee for pointing this out.
} 
ple results is that $G O V E R N A N C E_{j}$ now enters positively, as expected. Remaining conditioning variables entered insignificantly.

Note that the coefficient estimate on the $E M U_{i j t}^{\text {pair }}$ variable decreases dramatically when we move from Model 2 to 3, i.e. when the conditioning variables for GDP and bilateral trade are added. It therefore appears to be the case that part of the perceived EMU effect is picking up the increased volume of trade enjoyed by the EMU partner nations subsequent to the launch of the currency area. Still, the estimated economic impact of the pairwise EMU effect remains substantial with these variables included. Moreover, the increased bilateral trade subsequent to the launch of the EMU may be one of the channels through which financial integration was increased by the EMU 9

Table 5 estimates equation (3) for evidence of a "pure creditor" euro effect. Our sample consists of all pairs of creditors and non-EMU borrower countries. It can be seen that our variable of interest, $E M U_{i t}^{c r e d}$, enters with a positive coefficient estimate, but only at statistically significant levels when the conditioning variables are not included. Model 3 demonstrates that the variable fails to achieve statistical significance when we only condition for GDP and GDP per capita levels of creditors and borrowers, distance, and trade levels. Model 5 demonstrates that when we run the specification in levels the variable enters insignificantly with the incorrect sign.

The conditioning variables that enter are again $D I S T_{i j}, G D P_{j t}, G D P C A P_{j t}, T R A D E_{i j t}$, $B O R D E R_{i j}, I S L A N D_{j}, G O V E R N A N C E_{j}$, and $O F C_{j}$. In addition, we obtain a negative and significant coefficient on the $E C_{i}$ variable with the conditioning variables excluded, but the result is not robust to the inclusion of the conditioning variables. Indeed, with the full battery of conditioning variables in Model 5 the coefficient actually changes sign, but is highly insignificant. Remaining conditioning variables are again insignificant.

Finally, Table 6 repeats the exercise for the pure "borrower effect" of the advent of the euro

${ }^{9}$ For example, see Rose (2008). 
from equation (5). Our sample consists of all pairs of borrowers with non-EMU creditors. It can be seen that our variable of interest, $E M U_{i t}^{\text {borr }}$, always enters with a positive coefficient estimate, but is insignificant for all specifications. Even the distance variable is insignificant for the specifications that include the full set of conditioning variables. The only variables that robustly enter at statistically significant levels are $T R A D E_{i j t}$, which again enters with a statistically significant point estimate of 0.33 , and $O F C_{j}$, which again enters with a negative coefficient.

Overall, our results for isolated channels of the euro effect provide strong evidence of a positive pairwise effect of the advent of the euro, and much weaker evidence of a pure creditor or borrower effect.

\section{Robustness Checks}

\subsection{Early intervention dates}

The long process leading up to the EMU appears to have led to a response in lending patterns long before the formal union launch date. This can be seen in Table 1, as there was clearly a large increase in lending to Portugal and Greece prior to their respective formal EMU accessions. This anticipatory effect may reflect an effort by EMU member-country banks to establish market share at the expense of other EMU member-country banks under the expectation (which proved correct) that the pattern of member-country borrowing would shift towards EMU-partner nations subsequent to the launch of the monetary union. Alternatively, it may imply that the relative riskiness of borrowing from member states to other potential creditors had changed prior to formal EMU launch. In particular, currency risk exposure associated with borrowing in other EMU member currencies were probably reduced along to the path to Maastricht convergence.

Whatever its cause, the anticipatory pattern of lending implies some uncertainty about the timing of any euro effect. To allow for discrepancies in the timing of the euro effect, I consider the 
possibility of an anticipatory response five and three years before EMU accession. This corresponds to 1994 for the EMU creditor countries in our sample and Portugal, and 1996 for Greece for a five year anticipatory response, and 1996 for the EMU creditor countries in our sample and Portugal, and 1998 for Greece for a three-year anticipatory response.

We therefore consider the following alterations to our variables of interest for a five-year anticipatory effect: For the pairwise effect, we consider $E M U 9496_{i j t}^{\text {pair }}$, a dummy variable that takes value 1 for all observation pairs of lending by EMU creditor countries to Portugal in the year 1994 or later, and for all observation pairs of lending by EMU creditor countries to Greece in the year 1996 or later, and 0 otherwise. For the pure creditor effect, we consider $E M U 94_{i t}^{\text {cred }}$, a dummy variable that takes value 1 for all observation pairs of lending by EMU creditor countries in the year 1994 or later and 0 otherwise. For the pure borrower effect, we consider EMU9496 $6_{i t}^{\text {borr }}$, a dummy variable that takes value 1 for all observation pairs of borrowing by Portugal in the year 1994 or later, and for all observation pairs of borrowing by Greece in the year 1996 or later, and 0 otherwise. For the three-year anticipatory effect, we consider the analogous variables, EMU9698 ${ }_{i j t}^{\text {pair }}, E M U 96_{i t}^{\text {cred }}$, and $E M U 9698_{j t}^{\text {borr }}$.

Our results for a five-year anticipatory effect are shown in Table 7 . We include each of the euro effect channels separately with and without the conditioning variables, with the samples corresponding to that in Table 4 for Models 1 and 2 to examine the existence of a pairwise effect, to that in Table 5 for Models 3 and 4 to examine the existence of a pure creditor effect, and to that in Table 6 for Models 5 and 6 to examine the existence of a pure borrower effect.

The results for our variables of interest show that the pairwise variable, EMU9496 ${ }_{i j t}^{\text {pair }}$, is positive and significant with point estimates similar to those above. The pure creditor and debtor effect variables, $E M U 94_{i t}^{c r e d}$, and $E M U 9496_{j t}^{b o r r}$, are both insignificant. As usual, the distance variable always enters with a negative coefficient estimate, and is statistically significant for all models except Model 6. 
The performances of the remaining conditioning variables are similar to our earlier specifications. $G D P_{j t}$ comes in negatively at statistically significant levels for the pairwise and creditor effect samples, but just misses $10 \%$ significance for the borrower effect sample. The performance of $G D P C A P_{j t}$ is just the opposite, entering positively and with statistical significance for the pairwise and creditor effect samples, but just missing $10 \%$ significance for the borrower effect sample. The TRADE $E_{i j t}$ and $G O V E R N A N C E_{j}$ consistently enter significantly positive, while the $O F C_{j}$ variable consistently enters with a negative coefficient. Remaining conditioning variables are insignificant for at least two of the three models that include the conditioning variables.

Our results for a three-year anticipatory effect (Table 8) are similar. EMU9698 $8_{\text {ijt }}^{\text {pair }}$, is positive and significant with point estimates similar to those above. The pure creditor and debtor effect variables, $E M U 96_{i t}^{\text {cred }}$, and $E M U 9698_{j t}^{\text {borr }}$, are both insignificant. The distance variable again always enters with a negative coefficient estimate, and is statistically significant for all models except Model 6. the performances of the conditioning variables are very similar to those for the five-year anticipatory effect, with the exception that the GOVERNANCE $E_{j}$ variables is now insignificant for the pure borrower effect sample (Model 6).

\subsection{Interactive EMU effect}

Rather than taking the form of a uniform shift in lending levels, it is possible that the EMU effect manifested itself differently among different euro area countries. To investigate the sensitivity of the pairwise EMU effect to this possibility, I add variables to the specification representing the interaction of the $E M U_{i j t}^{\text {pair }}$ variable with the conditioning variables that entered the pairwise specification above with statistical significance 10 This results in a total of seven interactive variables.

I report the results in four specification in Table 9 below. First, I interact only the $D I S T_{i j}$ variable in Model 1. It can be seen that the $E M U_{i j t}^{\text {pair }}$ variable continues to enter positive and

\footnotetext{
${ }^{10}$ The full specification results were submitted to the referee and are available from the author upon request.
} 
significantly, suggesting the presence of a positive EMU effect. Models 2, 3, and 4 add the remaining interactive analogous to the specifications for Model 3, 4, and 5 in the specification for the pairwise

effect in Table 5. It can be seen that with the addition of these interactive terms the $E M U_{i j t}^{\text {pair }}$ variable is now very insignificant. However, it can be seen that the interactive $E M U_{i j t}^{\text {pair }} x T R A D E_{i j t}$ variable consistently enters positively at statistically significant levels.

Our analysis with the inclusion of interactive terms therefore confirms the presence of a pairwise EMU effect, but suggests that the EMU effect is stronger for countries that are more intensive trading partners. This is intuitive, as agents from country pairs that are more intensive trading partners may possess more information about economic conditions in the other country, leaving more opportunities for capitalizing on the benefits of monetary integration, such as reduced currency risk, between agents from these countries.

\subsection{Serial correlation}

Finally, there is the issue of serial correlation in conventional difference-in-differences applications discussed by Bertrand, Duflo, and Mullainathan (2004). As Bertrand, et al demonstrate, the high degree of serial correlation in both the dependent and policy variables commonly used in panel difference-in-differences exercises typically leads to an overstatement of the number of independent observations in one's sample.

A simple robustness check advocated by Bertrand, Duflo, and Mullainathan (2004) to deal with this issue is to remove the time dimension in the sample by aggregating the data into two time periods per observation. Intuitively, such a specification implies that the advent of the EMU implies a single change in agents' behavior at the time of its launch. For example, one would expect that loans denominated in local currency to some euro area countries would experience a persistent single reduction in currency risk exposure at the time of the launch of the euro. This would imply that neither the observations prior to nor those subsequent to the launch of the euro would be 
completely independent. Treating them as such would therefore result in underestimation of the size of the standard errors in our specification ${ }^{11}$

This approach requires the assumption that the treatment is supplied simultaneously. In our sample, the EMU creditors and Portugal enter the EMU in 1999, but Greece enters in 2001. to deal with this timing issue, I collapse the data for borrowing pairs of all creditors lending to nonEMU borrowers and Portugal into one observation containing average levels prior to 1999 and one observation containing average levels afterwards. For observation pairs containing lending to Greece, I collapse the data into one observation containing average levels prior to 1999 and one observation containing average levels after 2001. The data for 1999 and 2000 are therefore not used for lending to Greece to allow us to have one observation for each creditor-debtor pair matching periods before and after accession to the EMU.

Collapsing the data in this manner yields much smaller samples than those in the earlier portion of the study. For example, our pairwise specification without conditioning variables yields only yields 196 observations. This implies that we cannot estimate all of our conditioning variables as well as a full battery of borrower and creditor country fixed effects ${ }^{12}$ I therefore include the joint conditioning variables as well as the borrower-specific conditioning variables, but exclude the creditor conditioning variables which tended to enter insignificantly above anyway 13

The results are shown in Table 10. EMU $U_{i j t}^{\text {pair }}$ again enters positively and with statistical significance with or without the inclusion of the conditioning variables. The point estimates for this coefficient continue to indicate a substantive pairwise euro effect. $E M U_{i t}^{\text {cred }}$ enters positively and significantly without the conditioning variables added, but is not robust to the inclusion of

\footnotetext{
${ }^{11}$ It should be acknowledged that this alternative is also extreme, as there is likely to be some variation in, for example, the magnitude of currency risk, before and after the launch of the euro. However, this would imply that we are overestimating, rather than underestimating the value of our standard errors.

${ }^{12}$ Time dummies are obviously dropped for this exercise as we only have one observation before and after EMU accession for each borrower-creditor pair.

${ }^{13}$ I also ran the specifications with the full battery of conditioning variables and allowed the program to choose the conditioning variables to drop and obtained similar results.
} 
the conditioning variables. In contrast, $E M U_{j t}^{\text {borr }}$ fails to enter significantly with the conditioning variables excluded, but enters significantly positive with the conditioning variables included.

Our results for the conditioning variables also appear to be robust to collapsing the data into two observation per borrower-creditor pair. The the $D I S T_{i j}$ variable continues to enter robustly with its expected negative term. The $E C_{i}$ dummy enters significantly negatively for the pairwise samples (Models 1 and 2), but enters positively in the creditor effect samples (Models 3 and 4). The $T R A D E_{i j t}$ and $B O R D E R_{i j}$ variables continue to enter positively and significantly, although the $B O R D E R_{i j}$ variable is insignificant for the borrower effect sample (Model 6). the remaining variables are insignificant, with the exception of the $F R E N C H L A W_{j}$ variable, which enters pos-

itively at a $10 \%$ confidence level in the creditor effect sample (Model 4), and the $I S L A N D_{j}$ and $O F C_{j}$ variables, which enter negatively at $10 \%$ and $5 \%$ confidence levels respectively in the same sample. Remaining conditioning variables are insignificant.

Overall, our results support the notion that the most robust channel of the euro effect is the pairwise effect. There were specifications that yielded significant creditor and borrower effects as well, but these demonstrated sensitivity to the inclusion or exclusion of our conditioning variables.

\section{Conclusion}

This paper decomposes the widely-observed "euro-effect," under which accession to the European Monetary Union led to increased financial integration among EMU partner nations at the expense of integration with non-partner nations. Using BIS panel data for commercial bank flows, I identify a robust pairwise effect for EMU-accession, as lending between pairs of creditors and borrowers who entered the EMU increased much more than pairs of creditors and borrowers who did not. In contrast, the evidence for pure creditor or borrower effects of EMU accession was much less robust.

The results suggest that the increased financial integration observed in the data was not at- 
tributable to the "push" from generally more active lending by EMU-member creditors, nor a "pull" from generally more active EMU-member borrowers. Instead, it appears to have more to do with creditors and borrowers lending and borrowing from each other. One possible explanation for a pairwise euro effect is that is that intermediation needs are driven by the need for trade credit. Indeed, the interactive specification suggested that the pairwise euro effect is stronger for pairs of EMU partner countries with more bilateral trade. Another possibility is that reductions in currency risk exposure played a role in allowing for greater increases in intermediation between monetary union members. It may also be the case that borrowers within a monetary union perceive a higher penalty for defaulting on union partners than creditors from an outside country.

It should be noted that the large changes in lending patterns we observe with the advent of the euro do not necessarily imply large welfare gains. It could be the case that relatively minor changes in intermediation costs led to substantial shifts by EMU borrowers in favor of borrowing from EMU partner-country creditors. However, as noted above, these shifts in the pattern of lending were accompanied at the outset by substantial increases in the net borrowing positions of Portugal and Greece, suggesting that the expanded borrowing opportunities afforded by the advent of the euro had a substantive impact on capital flows between monetary union members.

Our results also raise the question of financial diversion. The loss of market share by creditors from non-EMU countries may reduce welfare in those countries, reducing the net change in global welfare attributable to the advent of the EMU. However, our finding of a significant pairwise effect, combined with the large observed increases in net borrowing by Portugal and Greece subsequent to EMU accession, suggests that the launch of the monetary union brought real reductions in the cost of intermediation within the union. As such, it appears likely that any welfare losses suffered by creditors from outside countries would be outweighed by the gains to welfare enjoyed by union members. 


\section{References}

Adam, K., T. Japelli, A. Menichini, M. Padula, and M. Pagano (2002): "Analyse, Compare and Apply Alternative Indicators and Monitoring Methodologies to Measure the Evolution of Capital Market Integration in the European Union," in Report to the European Commission.

Baele, L., A. Ferrando, P. Hördahl, E. Krylova, and C. Monnet (2004): "Measuring Financial Integration in the Euro Area," ECB Occasional Paper Series, (14).

Bertrand, M., E. Duflo, and S. Mullainathan (2004): "How Much Should We Trust Difference-In-Differences Estimates?," Quarterly Journal of Economics, 119(1), 249-275.

Besley, T., And A. Case (2000): "Unnatural Experiments? Estimating the Incidence of Endogenous Policies," Economic Journal, 110, F672-F694.

Blanchard, O., and F. Giavazzi (2002): "Current Account Deficits in the Euro Area: The End of the Feldstein-Horioka Puzzle," Brookings Papers on Economic Activity, 0(2), 147-86.

Cabral, I., F. Dierick, and J. Vesala (2002): "Banking Integration in the Euro Area," $E C B$ Occasional Paper Series, (6).

Canhoto, A., and J. Dermine (2003): "A Note on Banking Efficiency in Portugal, New vs. Old Banks," Journal of Banking and Finance, 27, 2087-2098.

Carbo-Valverde, S., E. J. Kane, and F. Rodriguez-Fernandez (2008): "Evidence of Differences in the Effectiveness of Safety-Net Management in European Union Countries," NBER Working Paper no. 13782.

Coeurdacier, N., and P. Martin (2006): "The Geography of Asset Trade and the Euro: Insiders and Outsiders," CEPR Discussion Paper 6032.

Galati, G., And K. Tsatsaronis (2003): "The Impact of the Euro on Europe's Financial Markets," Financial Markets, Institutions and Instruments, 12(3), 165-222.

Gourinchas, P.-O., And O. Jeanne (2006): "The Elusive Gains from Financial Integration," Review of Economic Studies, 73(3), 715-741.

Hale, G. B., and M. M. Spiegel (2008): "When Shall a Country Have Its Own Bond Market?: Evidence from Bond Issuance Before and After the Launch of the EMU," mimeo, January 8.

Hartmann, P., M. Manna, and A. Manzanares (2001): "The Microstructure of the Euro Money Market," Journal of International Money and Finance, 20, 895-948.

Japelli, T., And M. Pagano (2008): "Financial Market Integration Under EMU," European Economy Economic Papers, (312).

LAne, P. R. (2006a): "Global Bond Portfolios and EMU," International Journal of Central Banking, 2(2), 1-23. 
_ (2006b): "The Real Effects of EMU,” IIIS Discussion Paper 115.

Pagano, M., and E.-L. Von Thadden (2004): "The European Bond Markets Under EMU," Oxford Review of Economics Policy, 20(4), 531-554.

Papaspyrou, T. S. (2004): "EMU Strategies: Lessons from Past Experience in view of EU Enlargement," Bank of Greece Working Paper, No. 11.

Portes, R., And H. Rey (2005): "The Determinants of Cross-Border Equity Flows," Journal of International Economics, 65(2), 269-296.

Rose, A. (2000): "One Money, One Market: Estimating the Effect of Common Currencies on Trade," Economic Policy, 15, 7-45.

(2005): "One Reason Countries Pay Their Debts: Renegotiation and International Trade," Journal of Development Economics, 77, 189-206.

Rose, A. K. (2008): "EMU, Trade and Business Cycle Synchronization," mimeo.

Rose, A. K., and M. M. Spiegel (2004): "A Gravity Model of Sovereign Lending: Trade, Default and Credit," International Monetary Fund Staff Papers, 51(Special issue), 50-63.

Santos, J., and K. Tsatsaronis (2006): "The Cost of Barriers to Entry: Evidence from the Market for Corporate Euro Bond Underwriting," Cadernos do Mercado de Valores Mobiliaros, Edicao Especial, 15 Aniversario, 35-63.

Sørensen, C. K., And J. M. P. Gutiérrez (2006): "Euro Area Banking Sector Integration Using Hierarchical Cluster Analysis Techniques," .

SPIEGEL, M. M. (2008): "Monetary and Financial Integration: Evidence from the EMU," Journal of the Japanese and International Economies, forthcoming. 
Figure 1: Borrowing Before and After EMU Accession

\section{Borrowing by EMU Countries}

\section{Before EMU}
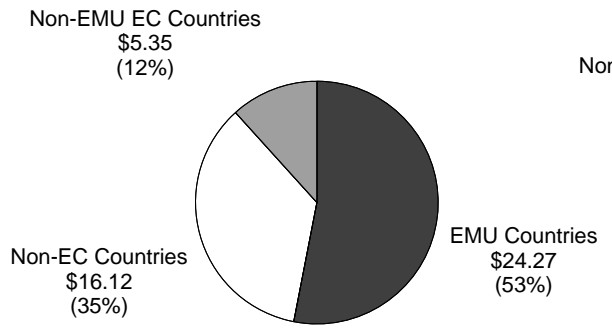

After EMU

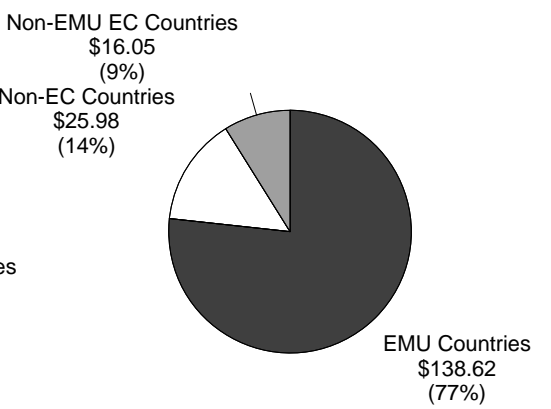

\section{Borrowing by Non-EMU Countries}

Before EMU

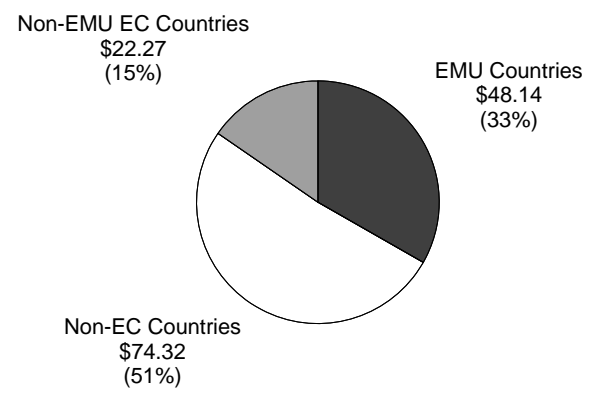

After EMU

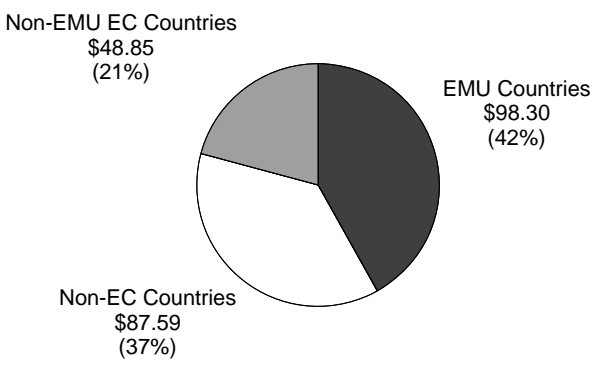

Note: Source: Bank for International Settlements (BIS). Annual averages in millions of 2000 U.S. dollars of commercial bank borrowing by EMU and non-EMU borrower countries before and after the advent of the euro. EMU creditor countries in the sample include Austria, Belgium, Finland, France, Germany, Italy, Netherlands, and Spain. Non-EMU EU creditor countries include Denmark, Sweden, and the United Kingdom. Non-EU creditor countries include Canada, Japan, Norway, Switzerland, and the United States. 
Figure 2: Borrowing and Lending by Non-EMU Borrowers and Creditors

\section{Borrowing by Non-EMU Borrowers}

Before EMU

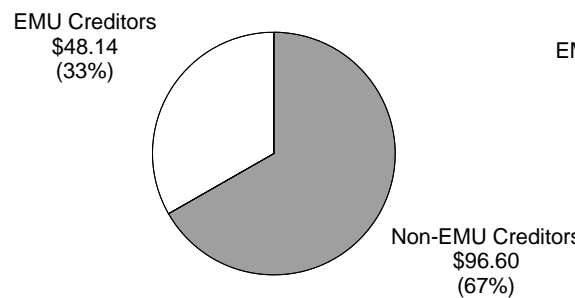

After EMU

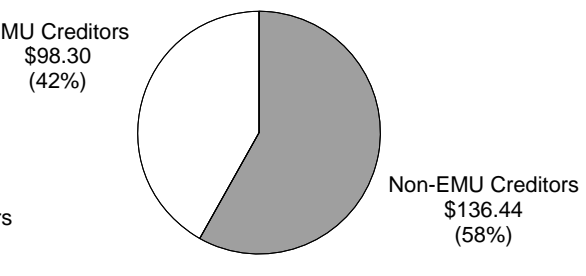

\section{Lending by Non-EMU Creditors}

Before EMU

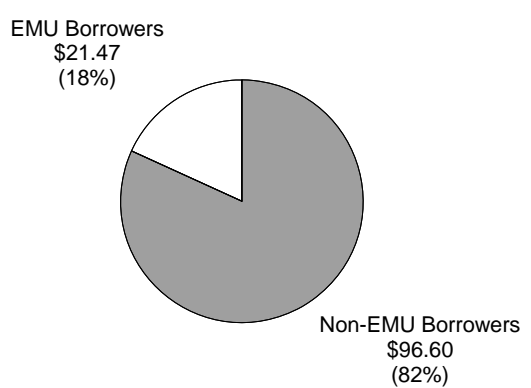

After EMU

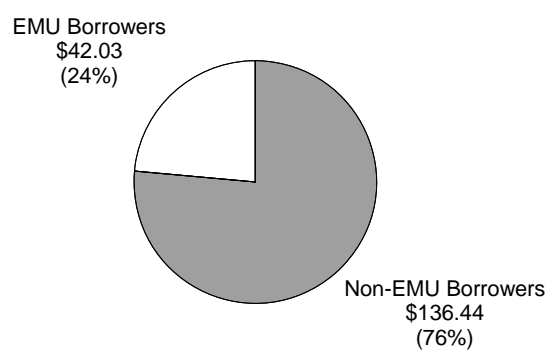

Note: Source: Bank for International Settlements (BIS). Annual averages in millions of 2000 U.S. dollars of commercial bank borrowing by non-EMU borrower countries before and after the advent of the euro. EMU creditor countries in the sample include Austria, Belgium, Finland, France, Germany, Italy, Netherlands, and Spain. Non-EMU EU creditor countries include Denmark, Sweden, and the United Kingdom. Non-EU creditor countries include Canada, Japan, Norway, Switzerland, and the United States. 
Table 1: Lending to Portugal and Greece

\begin{tabular}{|c|c|c|c|}
\hline \multirow[t]{2}{*}{ Portugal } & \multicolumn{2}{|c|}{ Pre-EMU } & \multirow{2}{*}{$\begin{array}{l}\text { Post-EMU } \\
1999-2006\end{array}$} \\
\hline & $1985-1991$ & 1992-1998 & \\
\hline \multirow[t]{2}{*}{ Non-EC Countries } & 6,972 & 4,548 & 5,623 \\
\hline & $(52.4 \%)$ & $(15.8 \%)$ & $(5.8 \%)$ \\
\hline \multicolumn{4}{|l|}{ Non-EMU EC Countries } \\
\hline \multirow[t]{2}{*}{ Excluding UK } & 221 & 262 & 301 \\
\hline & $(1.7 \%)$ & $(0.9 \%)$ & $(0.3 \%)$ \\
\hline$U K$ & 1,295 & 1,765 & 8,581 \\
\hline & $(9.7 \%)$ & $(6.1 \%)$ & $(8.8 \%)$ \\
\hline \multirow[t]{2}{*}{ EMU Countries } & 4,805 & 22,260 & 83,251 \\
\hline & $(36.1 \%)$ & $(77.2 \%)$ & $(85.2 \%)$ \\
\hline Total & 13,293 & 28,834 & 97,756 \\
\hline \multirow[t]{2}{*}{ Greece } & \multicolumn{2}{|c|}{ Pre-EMU } & Post-EMU \\
\hline & $1985-1991$ & 1992-2000 & 2001-2006 \\
\hline \multirow[t]{2}{*}{ Non-EC Countries } & 10,441 & 10,449 & 23,468 \\
\hline & $(51.1 \%)$ & $(31.2 \%)$ & $(25.0 \%)$ \\
\hline \multicolumn{4}{|l|}{ Non-EMU EC Countries } \\
\hline \multirow[t]{2}{*}{ Excluding $U K$} & 389 & 303 & 365 \\
\hline & $(1.9 \%)$ & $(0.9 \%)$ & $(0.4 \%)$ \\
\hline \multirow[t]{2}{*}{$U K$} & 1,975 & 4,743 & 7,213 \\
\hline & $(9.7 \%)$ & $(14.1 \%)$ & $(7.7 \%)$ \\
\hline \multirow[t]{2}{*}{ EMU Countries } & 7,627 & 18,038 & 62,918 \\
\hline & $(37.3 \%)$ & $(53.8 \%)$ & $(67.0 \%)$ \\
\hline Total & 20,432 & 33,533 & 93,964 \\
\hline
\end{tabular}

Notes: Source: Bank for International Settlements (BIS). Annual averages in millions of 2000 U.S. dollars of commercial bank borrowing by Portugal and Greece before and after the advent of the euro. EMU creditor countries in the sample include Austria, Belgium, Finland, France, Germany, Italy, Netherlands, and Spain. Non-EMU EU creditor countries include Denmark, Sweden, and the United Kingdom. Non-EU creditor countries include Canada, Japan, Norway, Switzerland, and the United States. 
Table 2: Borrowing by Non-EMU Debtors Before and After EMU Accession

\begin{tabular}{cccc}
\hline \hline & \multicolumn{2}{c}{ Pre-EMU } & Post-EMU \\
\cline { 2 - 4 } Non-EC Countries & $1985-1991$ & $1992-1998$ & $1999-2006$ \\
& 71,637 & 77,013 & 87,587 \\
Non-EMU EC Countries & $(59.3 \%)$ & $(45.7 \%)$ & $(37.3 \%)$ \\
Excluding UK & 612 & 811 & \\
& $(0.5 \%)$ & $(0.5 \%)$ & $(0.2 \%)$ \\
& 15,769 & 27,357 & 48,407 \\
EMU Countries & $(13.1 \%)$ & $(16.2 \%)$ & $(20.6 \%)$ \\
& 32,816 & 63,466 & 98,296 \\
Total & $(27.2 \%)$ & $(37.6 \%)$ & $(41.9 \%)$ \\
\hline \hline
\end{tabular}

Notes: Source: Bank for International Settlements (BIS). Annual averages in millions of 2000 U.S. dollars of commercial bank borrowing by non-EMU borrower countries before and after the advent of the euro. EMU creditor countries in the sample include Austria, Belgium, Finland, France, Germany, Italy, Netherlands, and Spain. Non-EMU EU creditor countries include Denmark, Sweden, and the United Kingdom. Non-EU creditor countries include Canada, Japan, Norway, Switzerland, and the United States. 
Table 3: OLS Results: Full Sample

\begin{tabular}{|c|c|c|c|c|c|}
\hline & $(1)$ & $(2)$ & (3) & $(4)$ & $(5)$ \\
\hline \multirow[t]{2}{*}{ CONSTANT } & 62.87 & 68.26 & 50.99 & $23.57^{* * *}$ & 45.01 \\
\hline & $(75.11)$ & $(76.77)$ & $(70.84)$ & $(1.35)$ & $(71.13)$ \\
\hline \multirow{2}{*}{$E M U_{i j t}^{\text {pair }}$} & $0.67^{* * *}$ & & & 0.56 & 0.37 \\
\hline & $(0.20)$ & & & $(0.36)$ & $(0.24)$ \\
\hline \multirow{2}{*}{$E M U_{j t}^{\text {borr }}$} & & $0.37^{* *}$ & & $0.38^{*}$ & 0.21 \\
\hline & & $(0.17)$ & & $(0.20)$ & $(0.17)$ \\
\hline \multirow{2}{*}{$E M U_{i t}^{\text {cred }}$} & & & 0.46 & 0.47 & 0.42 \\
\hline & & & $(0.30)$ & $(0.29)$ & $(0.32)$ \\
\hline \multirow{2}{*}{$D I S T_{i j}$} & $-0.30^{* *}$ & $-0.33^{* *}$ & $-0.34^{* *}$ & $-0.80 * * *$ & $-0.32^{* *}$ \\
\hline & $(0.12)$ & $(0.12)$ & $(0.12)$ & $(0.16)$ & $(0.12)$ \\
\hline \multirow[t]{2}{*}{$E C_{i}$} & 0.18 & -0.11 & 1.31 & $2.14^{* * *}$ & 1.23 \\
\hline & $(5.01)$ & $(5.19)$ & $(4.58)$ & $(0.10)$ & $(4.62)$ \\
\hline \multirow[t]{2}{*}{$E C_{j}$} & 0.00 & 0.00 & 0.00 & -0.46 & 0.00 \\
\hline & $(0.00)$ & $(0.00)$ & $(0.00)$ & $(0.39)$ & $(0.00)$ \\
\hline \multirow[t]{2}{*}{$G D P_{i t}$} & -1.01 & -1.35 & 0.16 & & 0.14 \\
\hline & $(3.44)$ & $(3.55)$ & $(3.32)$ & & $(3.34)$ \\
\hline \multirow{2}{*}{$G D P_{j t}$} & $-1.98 * * *$ & $-1.98^{* * *}$ & $-2.35^{* * *}$ & & $-1.95^{* *}$ \\
\hline & $(0.66)$ & $(0.66)$ & $(0.66)$ & & $(0.67)$ \\
\hline \multirow{2}{*}{$G D P C A P_{i t}$} & 1.29 & 1.75 & -0.28 & & -0.32 \\
\hline & $(3.72)$ & $(3.77)$ & $(3.87)$ & & $(3.89)$ \\
\hline \multirow[t]{2}{*}{$G D P C A P_{j t}$} & $2.20^{* * *}$ & $2.18^{* * *}$ & $2.59^{* * *}$ & & $2.16^{* * *}$ \\
\hline & $(0.65)$ & $(0.67)$ & $(0.65)$ & & $(0.68)$ \\
\hline \multirow[t]{2}{*}{$T R A D E_{i j t}$} & $0.34^{* * *}$ & $0.34^{* * *}$ & $0.33^{* * *}$ & & $0.33^{* * *}$ \\
\hline & $(0.08)$ & $(0.08)$ & $(0.08)$ & & $(0.08)$ \\
\hline \multirow[t]{2}{*}{$F R E N C H L A W_{j t}$} & $-3.17 * * *$ & $-3.19 * * *$ & $-3.59 * * *$ & & $-3.17 * * *$ \\
\hline & $(0.83)$ & $(0.83)$ & $(0.82)$ & & $(0.84)$ \\
\hline \multirow{2}{*}{$F R E N C H L A W_{i t}$} & 1.94 & 2.39 & 0.41 & & 0.41 \\
\hline & $(4.57)$ & $(4.72)$ & $(4.40)$ & & $(4.43)$ \\
\hline \multirow[t]{2}{*}{$B O R D E R_{i j}$} & $1.66^{* * *}$ & $1.65^{* * *}$ & $1.65^{* * *}$ & & $1.65^{* * *}$ \\
\hline & $(0.43)$ & $(0.44)$ & $(0.44)$ & & $(0.44)$ \\
\hline \multirow[t]{2}{*}{$I S L A N D_{j}$} & $-5.04 * * *$ & $-4.99 * * *$ & $-5.91 * * *$ & & $-4.98 * * *$ \\
\hline & $(1.55)$ & $(1.55)$ & $(1.54)$ & & $(1.58)$ \\
\hline \multirow[t]{2}{*}{$A R E A_{j}$} & $0.00^{* * *}$ & $0.00^{* * *}$ & $0.00^{* * *}$ & & $0.00^{* * *}$ \\
\hline & $(0.00)$ & $(0.00)$ & $(0.00)$ & & $(0.00)$ \\
\hline \multirow{2}{*}{$G O V E R N A N C E_{j}$} & $-0.40^{*}$ & $-0.40^{*}$ & $-0.45^{*}$ & & $-0.39^{*}$ \\
\hline & $(0.22)$ & $(0.23)$ & $(0.22)$ & & $(0.22)$ \\
\hline \multirow[t]{2}{*}{$G O V E R N A N C E_{i}$} & -2.26 & -2.99 & 0.21 & & 0.17 \\
\hline & $(7.56)$ & $(7.81)$ & $(7.23)$ & & $(7.29)$ \\
\hline \multirow{2}{*}{$O F C_{j}$} & $-7.99 * * *$ & $-7.95^{* * *}$ & $-9.11 * * *$ & & $-7.91 * * *$ \\
\hline & $(1.95)$ & $(1.99)$ & $(1.93)$ & & $(2.01)$ \\
\hline Observations & 7148 & 7148 & 7148 & 8072 & 7148 \\
\hline R-squared & 0.77 & 0.77 & 0.77 & 0.75 & 0.77 \\
\hline
\end{tabular}

Note: Dependent Variable: $L_{i j t}$. Full sample panel estimation by OLS with White's heteroskedasticity correction and clustering by creditor. Specifications include creditor country and time dummies, which are suppressed, along with conditioning variables $C O M L A N G_{i j}, I S L A N D_{i}, A R E A_{i}, L A N D L O C K E D_{i}$, $L A N D L O C K E D_{j}, O F C_{i}, T A X H A V E N_{i}, T A X H A V E N_{j}$. Estimates for suppressed variables available on request. Variables measured in dollars reported in logs. ${ }^{* * *}$ significant at 1 percent confidence level. ** significant at 5 percent confidence level. ${ }^{*}$ significant at 10 percent confidence level. 
Table 4: Test for a Pair Effect of EMU

\begin{tabular}{|c|c|c|c|c|c|c|}
\hline & $\overline{~(1) ~}$ & 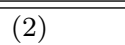 & 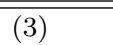 & $\overline{~(4)}$ & $\overline{~(5)}$ & 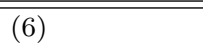 \\
\hline CONSTANT & $\begin{array}{l}16.79^{* * *} \\
(0.42)\end{array}$ & $\begin{array}{l}23.73^{* * *} \\
(1.90)\end{array}$ & $\begin{array}{l}69.46 \\
(63.98)\end{array}$ & $\begin{array}{l}64.73 \\
(56.85)\end{array}$ & $\begin{array}{l}63.64 \\
(66.12)\end{array}$ & $\begin{array}{l}2.40 \mathrm{e}+10^{* * *} \\
(7.98 \mathrm{e}+09)\end{array}$ \\
\hline$E M U_{i j t}^{\text {pair }}$ & $\begin{array}{l}1.39^{* * *} \\
(0.31)\end{array}$ & $\begin{array}{l}1.41^{* * *} \\
(0.31)\end{array}$ & $\begin{array}{l}1.06^{* * *} \\
(0.33)\end{array}$ & $\begin{array}{l}1.07^{* * *} \\
(0.33)\end{array}$ & $\begin{array}{l}1.07 * * * \\
(0.33)\end{array}$ & $\begin{array}{l}7.28 \mathrm{e}+09 * * \\
(2.47 \mathrm{e}+09)\end{array}$ \\
\hline$E C_{i}$ & $\begin{array}{l}1.46^{* * *} \\
(0.29)\end{array}$ & $\begin{array}{l}0.59 \\
(0.36)\end{array}$ & $\begin{array}{l}-2.28 \\
(11.38)\end{array}$ & $\begin{array}{l}0.18 \\
(2.13)\end{array}$ & $\begin{array}{l}0.19 \\
(3.08)\end{array}$ & $\begin{array}{l}552197705.18 \\
(1.68 \mathrm{e}+09)\end{array}$ \\
\hline$E C_{j}$ & $\begin{array}{l}1.05^{* * *} \\
(0.34)\end{array}$ & $\begin{array}{l}0.30 \\
(0.50)\end{array}$ & $\begin{array}{l}0.00 \\
(0.00)\end{array}$ & $\begin{array}{l}0.00 \\
(0.00)\end{array}$ & $\begin{array}{l}0.00 \\
(0.00)\end{array}$ & $\begin{array}{l}-8.28 \mathrm{e}+09^{* * *} \\
(2.09 \mathrm{e}+09)\end{array}$ \\
\hline$D I S T_{i j}$ & & $\begin{array}{l}-0.85^{* * *} \\
(0.22)\end{array}$ & $\begin{array}{l}-0.47^{* *} \\
(0.21)\end{array}$ & $\begin{array}{l}-0.40^{*} \\
(0.21)\end{array}$ & $\begin{array}{l}-0.40^{*} \\
(0.21)\end{array}$ & $\begin{array}{l}-2.87 \mathrm{e}+09^{* * *} \\
(788346825.10)\end{array}$ \\
\hline$G D P_{i t}$ & & & $\begin{array}{l}0.21 \\
(2.94)\end{array}$ & $\begin{array}{l}0.14 \\
(2.93)\end{array}$ & $\begin{array}{l}0.14 \\
(2.93)\end{array}$ & \\
\hline$G D P_{j t}$ & & & $\begin{array}{l}-2.55^{* *} \\
(1.08)\end{array}$ & $\begin{array}{l}-2.53^{* *} \\
(1.08)\end{array}$ & $\begin{array}{l}-2.53^{* *} \\
(1.08)\end{array}$ & \\
\hline$G D P C A P_{i t}$ & & & $\begin{array}{l}-1.18 \\
(3.85)\end{array}$ & $\begin{array}{l}-1.12 \\
(3.88)\end{array}$ & $\begin{array}{l}-1.12 \\
(3.88)\end{array}$ & \\
\hline$G D P C A P_{j t}$ & & & $\begin{array}{l}2.24^{*} \\
(1.08)\end{array}$ & $\begin{array}{l}2.21^{*} \\
(1.08)\end{array}$ & $\begin{array}{l}2.21^{*} \\
(1.08)\end{array}$ & \\
\hline$T R A D E_{i j t}$ & & & $\begin{array}{l}0.43^{* * *} \\
(0.11)\end{array}$ & $\begin{array}{l}0.43^{* * *} \\
(0.10)\end{array}$ & $\begin{array}{l}0.43^{* * *} \\
(0.10)\end{array}$ & \\
\hline$B O R D E R_{i j}$ & & & & $\begin{array}{l}1.38^{* * *} \\
(0.26)\end{array}$ & $\begin{array}{l}1.38^{* * *} \\
(0.26)\end{array}$ & \\
\hline$I S L A N D_{j}$ & & & & $\begin{array}{l}-16.30^{*} \\
(7.87)\end{array}$ & $\begin{array}{l}-6.77^{*} \\
(3.65)\end{array}$ & \\
\hline$A R E A_{j}$ & & & & $\begin{array}{l}0.00 \\
(0.00)\end{array}$ & $\begin{array}{l}0.00 \\
(0.00)\end{array}$ & \\
\hline$F R E N C H L A W_{j t}$ & & & & & $\begin{array}{l}-1.08 \\
(2.12)\end{array}$ & \\
\hline$F R E N C H L A W_{i t}$ & & & & & $\begin{array}{l}-1.57 \\
(7.46)\end{array}$ & \\
\hline$G O V E R N A N C E_{j}$ & & & & & $\begin{array}{l}1.67^{* * *} \\
(0.56)\end{array}$ & \\
\hline$G O V E R N A N C E_{i}$ & & & & & $\begin{array}{l}-0.01 \\
(6.38)\end{array}$ & \\
\hline$O F C_{j}$ & & & & & $\begin{array}{l}-8.20^{* *} \\
(3.75)\end{array}$ & \\
\hline Observations & 3621 & 3621 & 3302 & 3302 & 3302 & 3621 \\
\hline R-squared & 0.78 & 0.80 & 0.83 & 0.83 & 0.83 & 0.45 \\
\hline
\end{tabular}

Note: Dependent Variable: $L_{i j t}$. Panel estimation by ordinary least squares with White's heteroskedasticity correction and clustering by creditor. Sample restricted to pairs of countries with both EMU country borrowers and EMU country creditors and pairs of countries where neither borrowers nor creditors entered the EMU. Specifications include creditor country and time dummies, which are suppressed, along with conditioning variables COMLANG $G_{i j}, I S L A N D_{i}, A R E A_{i}, L A N D L O C K E D_{i}, L A N D L O C K E D_{j}, O F C_{i}$, $T A X H A V E N_{i}, T A X H A V E N_{j}$. Estimates for suppressed variables available on request. Variables measured in dollars reported in logs, with the exception of Model 6 which reports results for estimation in levels. *** significant at 1 percent confidence level. ${ }^{* *}$ significant at 5 percent confidence level. ${ }^{*}$ significant at 10 percent confidence level. 
Table 5: Test for a Creditor Effect of EMU

\begin{tabular}{|c|c|c|c|c|c|c|}
\hline & (1) & $(2)$ & (3) & (4) & (5) & $(6)$ \\
\hline CONSTANT & $\begin{array}{l}19.96^{* * *} \\
(0.31)\end{array}$ & $\begin{array}{l}27.42^{* * *} \\
(1.75)\end{array}$ & $\begin{array}{l}58.39 \\
(68.77)\end{array}$ & $\begin{array}{l}47.02 \\
(55.36)\end{array}$ & $\begin{array}{l}41.77 \\
(66.04)\end{array}$ & $\begin{array}{l}2.08 \mathrm{e}+10^{* * *} \\
(4.20 \mathrm{e}+09)\end{array}$ \\
\hline$E M U_{i t}^{\text {cred }}$ & $\begin{array}{l}0.48^{*} \\
(0.26)\end{array}$ & $\begin{array}{l}0.45^{*} \\
(0.25)\end{array}$ & $\begin{array}{l}0.37 \\
(0.29)\end{array}$ & $\begin{array}{l}0.39 \\
(0.29)\end{array}$ & $\begin{array}{l}0.39 \\
(0.29)\end{array}$ & $\begin{array}{l}-77407838.94 \\
(512241374.96)\end{array}$ \\
\hline$E C_{i}$ & $\begin{array}{l}-0.41^{* * *} \\
(0.07)\end{array}$ & $\begin{array}{l}-0.55^{* * *} \\
(0.07)\end{array}$ & $\begin{array}{l}-1.85 \\
(11.24)\end{array}$ & $\begin{array}{l}-1.33 \\
(0.81)\end{array}$ & $\begin{array}{l}1.87 \\
(8.06)\end{array}$ & $\begin{array}{l}-3.35 \mathrm{e}+08^{* *} \\
(132920135.89)\end{array}$ \\
\hline$E C_{j}$ & $\begin{array}{l}0.00 \\
(0.00)\end{array}$ & $\begin{array}{l}0.00 \\
(0.00)\end{array}$ & $\begin{array}{l}0.00 \\
(0.00)\end{array}$ & $\begin{array}{l}0.00 \\
(0.00)\end{array}$ & $\begin{array}{l}0.00 \\
(0.00)\end{array}$ & $\begin{array}{l}0.00 \\
(0.00)\end{array}$ \\
\hline$D I S T_{i j}$ & & $\begin{array}{l}-0.94^{* * *} \\
(0.22)\end{array}$ & $\begin{array}{l}-0.56^{* *} \\
(0.23)\end{array}$ & $\begin{array}{l}-0.52^{* *} \\
(0.18)\end{array}$ & $\begin{array}{l}-0.52^{* *} \\
(0.18)\end{array}$ & $\begin{array}{l}-2.35 \mathrm{e}+09^{* * *} \\
(478763910.79)\end{array}$ \\
\hline$G D P_{i t}$ & & & $\begin{array}{l}-0.19 \\
(3.24)\end{array}$ & $\begin{array}{l}0.51 \\
(3.17)\end{array}$ & $\begin{array}{l}0.51 \\
(3.17)\end{array}$ & \\
\hline$G D P_{j t}$ & & & $\begin{array}{l}-1.80^{* *} \\
(0.68)\end{array}$ & $\begin{array}{l}-1.89 * * \\
(0.69)\end{array}$ & $\begin{array}{l}-1.89 * * \\
(0.69)\end{array}$ & \\
\hline$G D P C A P_{i t}$ & & & $\begin{array}{l}-0.55 \\
(3.59)\end{array}$ & $\begin{array}{l}-1.14 \\
(3.67)\end{array}$ & $\begin{array}{l}-1.14 \\
(3.67)\end{array}$ & \\
\hline$G D P C A P_{j t}$ & & & $\begin{array}{l}2.01^{* * *} \\
(0.66)\end{array}$ & $\begin{array}{l}2.20^{* * *} \\
(0.69)\end{array}$ & $\begin{array}{l}2.20^{* * *} \\
(0.69)\end{array}$ & \\
\hline$T R A D E_{i j t}$ & & & $\begin{array}{l}0.40^{* * *} \\
(0.11)\end{array}$ & $\begin{array}{l}0.33^{* * *} \\
(0.09)\end{array}$ & $\begin{array}{l}0.33^{* * *} \\
(0.09)\end{array}$ & \\
\hline$B O R D E R_{i j}$ & & & & $\begin{array}{l}1.20^{*} \\
(0.66)\end{array}$ & $\begin{array}{l}1.20^{*} \\
(0.66)\end{array}$ & \\
\hline$I S L A N D_{j}$ & & & & $\begin{array}{l}-15.88^{* * *} \\
(4.62)\end{array}$ & $\begin{array}{l}-9.22^{* * * *} \\
(2.71)\end{array}$ & \\
\hline$A R E A_{j}$ & & & & $\begin{array}{l}0.00 \\
(0.00)\end{array}$ & $\begin{array}{l}-0.00 \\
(0.00)\end{array}$ & \\
\hline$F R E N C H L A W_{j t}$ & & & & & $\begin{array}{l}2.23^{* * *} \\
(0.68)\end{array}$ & \\
\hline$F R E N C H L A W_{i t}$ & & & & & $\begin{array}{l}-0.84 \\
(8.06)\end{array}$ & \\
\hline$G O V E R N A N C E_{j}$ & & & & & $\begin{array}{l}1.96^{* * *} \\
(0.49)\end{array}$ & \\
\hline$G O V E R N A N C E_{i}$ & & & & & $\begin{array}{l}1.03 \\
(6.90)\end{array}$ & \\
\hline$O F C_{j}$ & & & & & $\begin{array}{l}-9.25^{* * *} \\
(2.56)\end{array}$ & \\
\hline Observations & 6741 & 6741 & 5911 & 5911 & 5911 & 6741 \\
\hline $\mathrm{R}$-squared & 0.70 & 0.72 & 0.74 & 0.75 & 0.75 & 0.36 \\
\hline
\end{tabular}

Note: Dependent Variable: $L_{i j t}$. Panel estimation by ordinary least squares with White's heteroskedasticity correction and clustering by creditor. Sample restricted to all pairs of creditors and non-EMU borrower countries. Specifications include creditor country and time dummies, which are suppressed, along with conditioning variables COMLANG $G_{i j}, I S L A N D_{i}, A R E A_{i}, L A N D L O C K E D_{i}, L A N D L O C K E D_{j}, O F C_{i}$, $T A X H A V E N_{i}, T A X H A V E N_{j}$. Estimates for suppressed variables available on request. Variables measured in dollars reported in logs, with the exception of Model 6 which reports results for estimation in levels. *** significant at 1 percent confidence level. ${ }^{* *}$ significant at 5 percent confidence level. ${ }^{*}$ significant at 10 percent confidence level. 
Table 6: Test for a Debtor Effect of EMU

\begin{tabular}{|c|c|c|c|c|c|c|}
\hline & (1) & $(2)$ & (3) & (4) & $(5)$ & (6) \\
\hline CONSTANT & $\begin{array}{l}19.99^{* * *} \\
(0.38)\end{array}$ & $\begin{array}{l}24.86^{* * *} \\
(1.45)\end{array}$ & $\begin{array}{l}39.57 \\
(80.72)\end{array}$ & $\begin{array}{l}41.92 \\
(67.76)\end{array}$ & $\begin{array}{l}41.79 \\
(71.15)\end{array}$ & $\begin{array}{l}1.76 \mathrm{e}+10^{* *} \\
(5.08 \mathrm{e}+09)\end{array}$ \\
\hline$E M U_{j t}^{b o r r}$ & $\begin{array}{l}0.22 \\
(0.22)\end{array}$ & $\begin{array}{l}0.23 \\
(0.21)\end{array}$ & $\begin{array}{l}0.06 \\
(0.21)\end{array}$ & $\begin{array}{l}0.07 \\
(0.21)\end{array}$ & $\begin{array}{l}0.07 \\
(0.21)\end{array}$ & $\begin{array}{l}1.03 \mathrm{e}+09 \\
(806342484.92)\end{array}$ \\
\hline$E C_{i}$ & $\begin{array}{l}-1.56^{* * *} \\
(0.10)\end{array}$ & $\begin{array}{l}-1.64^{* * *} \\
(0.07)\end{array}$ & $\begin{array}{l}0.56 \\
(13.86)\end{array}$ & $\begin{array}{l}-0.10 \\
(1.28)\end{array}$ & $\begin{array}{l}0.10 \\
(2.70)\end{array}$ & $\begin{array}{l}-4.90 \mathrm{e}+08^{* * *} \\
(106645652.13)\end{array}$ \\
\hline$E C_{j}$ & $\begin{array}{l}-0.52 \\
(0.50)\end{array}$ & $\begin{array}{l}-0.75 \\
(0.43)\end{array}$ & $\begin{array}{l}-1.93 \\
(1.28)\end{array}$ & $\begin{array}{l}-1.90 \\
(1.70)\end{array}$ & $\begin{array}{l}0.00 \\
(0.00)\end{array}$ & $\begin{array}{c}-3.34 \mathrm{e}+09^{*} \\
(1.43 \mathrm{e}+09)\end{array}$ \\
\hline$D I S T_{i j}$ & & $\begin{array}{l}-0.61^{* * *} \\
(0.17)\end{array}$ & $\begin{array}{l}-0.23 \\
(0.17)\end{array}$ & $\begin{array}{l}-0.21 \\
(0.18)\end{array}$ & $\begin{array}{l}-0.21 \\
(0.18)\end{array}$ & $\begin{array}{l}-1.93 \mathrm{e}+09^{* * *} \\
(531053995.92)\end{array}$ \\
\hline$G D P_{i t}$ & & & $\begin{array}{l}0.97 \\
(3.56)\end{array}$ & $\begin{array}{l}0.85 \\
(3.54)\end{array}$ & $\begin{array}{l}0.85 \\
(3.54)\end{array}$ & \\
\hline$G D P_{j t}$ & & & $\begin{array}{l}-1.40 \\
(1.01)\end{array}$ & $\begin{array}{l}-1.40 \\
(1.02)\end{array}$ & $\begin{array}{l}-1.40 \\
(1.02)\end{array}$ & \\
\hline$G D P C A P_{i t}$ & & & $\begin{array}{l}-2.83 \\
(4.66)\end{array}$ & $\begin{array}{l}-2.72 \\
(4.67)\end{array}$ & $\begin{array}{l}-2.72 \\
(4.67)\end{array}$ & \\
\hline$G D P C A P_{j t}$ & & & $\begin{array}{l}1.47 \\
(1.11)\end{array}$ & $\begin{array}{l}1.45 \\
(1.11)\end{array}$ & $\begin{array}{l}1.45 \\
(1.11)\end{array}$ & \\
\hline$T R A D E_{i j t}$ & & & $\begin{array}{l}0.40^{* * *} \\
(0.09)\end{array}$ & $\begin{array}{l}0.42^{* * *} \\
(0.08)\end{array}$ & $\begin{array}{l}0.42^{* * *} \\
(0.08)\end{array}$ & \\
\hline$B O R D E R_{i j}$ & & & & $\begin{array}{l}0.00 \\
(0.00)\end{array}$ & $\begin{array}{l}0.00 \\
(0.00)\end{array}$ & \\
\hline$I S L A N D_{j}$ & & & & $\begin{array}{l}-3.80 \\
(2.75)\end{array}$ & $\begin{array}{l}-3.10 \\
(2.04)\end{array}$ & \\
\hline$A R E A_{j}$ & & & & $\begin{array}{l}0.00 \\
(0.00)\end{array}$ & $\begin{array}{l}0.00^{* *} \\
(0.00)\end{array}$ & \\
\hline$F R E N C H L A W_{j t}$ & & & & & $\begin{array}{l}-2.30 \\
(1.36)\end{array}$ & \\
\hline$F R E N C H L A W_{i t}$ & & & & & $\begin{array}{l}0.00 \\
(0.00)\end{array}$ & \\
\hline$G O V E R N A N C E_{j}$ & & & & & $\begin{array}{l}-0.42 \\
(0.43)\end{array}$ & \\
\hline$G O V E R N A N C E_{i}$ & & & & & $\begin{array}{l}0.00 \\
(0.00)\end{array}$ & \\
\hline$O F C_{j}$ & & & & & $\begin{array}{l}-6.41^{*} \\
(3.25)\end{array}$ & \\
\hline Observations & 3576 & 3576 & 3315 & 3315 & 3315 & 3576 \\
\hline $\mathrm{R}$-squared & 0.77 & 0.79 & 0.81 & 0.81 & 0.81 & 0.37 \\
\hline
\end{tabular}

Note: Dependent Variable: $L_{i j t}$. Panel estimation by ordinary least squares with White's heteroskedasticity correction and clustering by creditor. Sample restricted to all pairs of borrowers with non-EMU creditors. Specifications include creditor country and time dummies, which are suppressed, along with conditioning variables COMLANG $G_{i j}, I S L A N D_{i}, A R E A_{i}, L A N D L O C K E D_{i}, L A N D L O C K E D_{j}, O F C_{i}, T_{A X H A V E N}$, $T A X H A V E N_{j}$. Estimates for suppressed variables available on request. Variables measured in dollars reported in logs, with the exception of Model 6 which reports results for estimation in levels. ${ }^{* * *}$ significant at 1 percent confidence level. ${ }^{* *}$ significant at 5 percent confidence level. ${ }^{*}$ significant at 10 percent confidence level. 
Table 7: Break date 5 years prior to EMU accession

\begin{tabular}{|c|c|c|c|c|c|c|}
\hline & $(1)$ & $(2)$ & $(3)$ & $(4)$ & $(5)$ & $(6)$ \\
\hline CONSTANT & $\begin{array}{l}23.81^{* * *} \\
(1.90)\end{array}$ & $\begin{array}{l}48.88 \\
(71.53)\end{array}$ & $\begin{array}{l}27.43^{* * *} \\
(1.73)\end{array}$ & $\begin{array}{l}31.12 \\
(67.01)\end{array}$ & $\begin{array}{l}24.86^{* * * *} \\
(1.44)\end{array}$ & $\begin{array}{l}41.87 \\
(69.99)\end{array}$ \\
\hline EMU9496 & $\begin{array}{l}1.24^{* * *} \\
(0.36)\end{array}$ & $\begin{array}{l}0.93^{* *} \\
(0.42)\end{array}$ & & & & \\
\hline$E M U 94_{i t}^{c r e d}$ & & & $\begin{array}{l}0.44 \\
(0.27)\end{array}$ & $\begin{array}{l}0.46 \\
(0.34)\end{array}$ & & \\
\hline$E M U 9496_{j t}^{b o r r}$ & & & & & $\begin{array}{l}0.06 \\
(0.18)\end{array}$ & $\begin{array}{l}-0.10 \\
(0.17)\end{array}$ \\
\hline$D I S T_{i j}$ & $\begin{array}{l}-0.85^{* * *} \\
(0.22)\end{array}$ & $\begin{array}{c}-0.40^{*} \\
(0.21)\end{array}$ & $\begin{array}{l}-0.93^{* * *} \\
(0.22)\end{array}$ & $\begin{array}{l}-0.51^{* *} \\
(0.18)\end{array}$ & $\begin{array}{l}-0.61^{* * *} \\
(0.17)\end{array}$ & $\begin{array}{l}-0.21 \\
(0.18)\end{array}$ \\
\hline$E C_{i}$ & $\begin{array}{l}0.56 \\
(0.37)\end{array}$ & $\begin{array}{l}-0.19 \\
(3.18)\end{array}$ & $\begin{array}{l}-0.68^{* * *} \\
(0.14)\end{array}$ & $\begin{array}{l}-0.04 \\
(8.33)\end{array}$ & $\begin{array}{l}-1.64^{* * *} \\
(0.07)\end{array}$ & $\begin{array}{l}0.09 \\
(2.69)\end{array}$ \\
\hline$E C_{j}$ & $\begin{array}{l}0.07 \\
(0.48)\end{array}$ & $\begin{array}{l}0.00 \\
(0.00)\end{array}$ & $\begin{array}{l}0.00 \\
(0.00)\end{array}$ & $\begin{array}{l}0.00 \\
(0.00)\end{array}$ & $\begin{array}{l}-0.71 \\
(0.44)\end{array}$ & $\begin{array}{l}0.00 \\
(0.00)\end{array}$ \\
\hline$G D P_{i t}$ & & $\begin{array}{l}0.52 \\
(3.05)\end{array}$ & & $\begin{array}{l}1.15 \\
(3.21)\end{array}$ & & $\begin{array}{l}0.83 \\
(3.51)\end{array}$ \\
\hline$G D P_{j t}$ & & $\begin{array}{l}-2.22^{*} \\
(1.08)\end{array}$ & & $\begin{array}{l}-1.89^{* *} \\
(0.69)\end{array}$ & & $\begin{array}{l}-1.61 \\
(1.05)\end{array}$ \\
\hline$G D P C A P_{i t}$ & & $\begin{array}{l}-1.49 \\
(3.92)\end{array}$ & & $\begin{array}{l}-1.96 \\
(3.80)\end{array}$ & & $\begin{array}{l}-2.69 \\
(4.63)\end{array}$ \\
\hline$G D P C A P_{j t}$ & & $\begin{array}{l}2.13^{*} \\
(1.09)\end{array}$ & & $\begin{array}{l}2.18^{* * *} \\
(0.70)\end{array}$ & & $\begin{array}{l}1.64 \\
(1.09)\end{array}$ \\
\hline$T R A D E_{i j t}$ & & $\begin{array}{l}0.43^{* * *} \\
(0.10)\end{array}$ & & $\begin{array}{l}0.34^{* * *} \\
(0.09)\end{array}$ & & $\begin{array}{l}0.42^{* * *} \\
(0.08)\end{array}$ \\
\hline$F R E N C H L A W_{j t}$ & & $\begin{array}{l}-1.19 \\
(2.15)\end{array}$ & & $\begin{array}{l}2.23^{* * *} \\
(0.68)\end{array}$ & & $\begin{array}{l}-1.11 \\
(0.73)\end{array}$ \\
\hline$F R E N C H L A W_{i t}$ & & $\begin{array}{l}-0.61 \\
(7.83)\end{array}$ & & $\begin{array}{l}0.76 \\
(8.19)\end{array}$ & & $\begin{array}{l}0.00 \\
(0.00)\end{array}$ \\
\hline$B O R D E R_{i j}$ & & $\begin{array}{l}1.36^{* * *} \\
(0.27)\end{array}$ & & $\begin{array}{l}1.16 \\
(0.67)\end{array}$ & & $\begin{array}{l}0.00 \\
(0.00)\end{array}$ \\
\hline$I S L A N D_{j}$ & & $\begin{array}{l}-5.69 \\
(3.89)\end{array}$ & & $\begin{array}{l}-9.18^{* * *} \\
(2.73)\end{array}$ & & $\begin{array}{l}-3.91 \\
(2.26)\end{array}$ \\
\hline$A R E A_{j}$ & & $\begin{array}{l}0.00 \\
(0.00)\end{array}$ & & $\begin{array}{l}-0.00 \\
(0.00)\end{array}$ & & $\begin{array}{l}0.00^{* *} \\
(0.00)\end{array}$ \\
\hline$G O V E R N A N C E_{j}$ & & $\begin{array}{l}1.45^{* *} \\
(0.59)\end{array}$ & & $\begin{array}{l}1.95^{* * *} \\
(0.50)\end{array}$ & & $\begin{array}{l}1.15^{* *} \\
(0.46)\end{array}$ \\
\hline$G O V E R N A N C E_{i}$ & & $\begin{array}{l}0.85 \\
(6.67)\end{array}$ & & $\begin{array}{l}2.42 \\
(7.01)\end{array}$ & & $\begin{array}{l}0.00 \\
(0.00)\end{array}$ \\
\hline$O F C_{j}$ & & $\begin{array}{l}-7.11^{*} \\
(3.99)\end{array}$ & & $\begin{array}{l}-9.21^{* * *} \\
(2.57)\end{array}$ & & $\begin{array}{l}-5.29 * \\
(2.50)\end{array}$ \\
\hline Observations & 3621 & 3302 & 6741 & 5911 & 3576 & 3315 \\
\hline R-squared & 0.80 & 0.83 & 0.72 & 0.75 & 0.79 & 0.81 \\
\hline
\end{tabular}

Note: Dependent Variable: $L_{i j t}$. Panel estimation by ordinary least squares with White's heteroskedasticity correction and clustering by creditor. See notes for tables 4, 5, and 6 for sample restrictions. Specifications include creditor country and time dummies, which are suppressed, along with conditioning variables COMLANG $G_{i j}, I S L A N D_{i}, A R E A_{i}, L A N D L O C K E D_{i}, L A N D L O C K E D_{j}, O F C_{i}, T_{A X H A V E N}$, $T A X H A V E N_{j}$. Estimates for suppressed variables available on request. Variables measured in dollars reported in logs. ${ }^{* * *}$ significant at 1 percent confidence level. ${ }^{* *}$ significant at 5 percent confidence level. $*$ significant at 10 percent confidence level. 
Table 8: Break date 3 years prior to EMU accession

\begin{tabular}{|c|c|c|c|c|c|c|}
\hline & $(1)$ & $(2)$ & $(3)$ & $(4)$ & $(5)$ & $(6)$ \\
\hline CONSTANT & $\begin{array}{l}23.78^{* * *} \\
(1.90)\end{array}$ & $\begin{array}{l}51.93 \\
(68.48)\end{array}$ & $\begin{array}{l}27.42^{* * * *} \\
(1.74)\end{array}$ & $\begin{array}{l}31.84 \\
(66.38)\end{array}$ & $\begin{array}{l}24.86^{* * * *} \\
(1.44)\end{array}$ & $\begin{array}{l}43.17 \\
(70.66)\end{array}$ \\
\hline$E M U 9698_{i j t}^{\text {pair }}$ & $\begin{array}{l}1.29^{* * *} \\
(0.34)\end{array}$ & $\begin{array}{l}0.99 * * \\
(0.39)\end{array}$ & & & & \\
\hline$E M U 96_{i t}^{c r e d}$ & & & $\begin{array}{l}0.46 \\
(0.27)\end{array}$ & $\begin{array}{l}0.46 \\
(0.33)\end{array}$ & & \\
\hline$E M U 9698_{j t}^{b o r r}$ & & & & & $\begin{array}{l}0.13 \\
(0.18)\end{array}$ & $\begin{array}{l}-0.01 \\
(0.16)\end{array}$ \\
\hline$D I S T_{i j}$ & $\begin{array}{l}-0.85^{* * *} \\
(0.22)\end{array}$ & $\begin{array}{c}-0.40^{*} \\
(0.21)\end{array}$ & $\begin{array}{l}-0.93^{* * *} \\
(0.22)\end{array}$ & $\begin{array}{l}-0.52^{* *} \\
(0.18)\end{array}$ & $\begin{array}{l}-0.61^{* * *} \\
(0.17)\end{array}$ & $\begin{array}{l}-0.21 \\
(0.18)\end{array}$ \\
\hline$E C_{i}$ & $\begin{array}{l}0.56 \\
(0.37)\end{array}$ & $\begin{array}{l}-0.17 \\
(3.15)\end{array}$ & $\begin{array}{l}-0.63^{* * *} \\
(0.12)\end{array}$ & $\begin{array}{l}0.11 \\
(8.33)\end{array}$ & $\begin{array}{l}-1.64^{* * *} \\
(0.07)\end{array}$ & $\begin{array}{l}0.10 \\
(2.69)\end{array}$ \\
\hline$E C_{j}$ & $\begin{array}{l}0.17 \\
(0.49)\end{array}$ & $\begin{array}{l}0.00 \\
(0.00)\end{array}$ & $\begin{array}{l}0.00 \\
(0.00)\end{array}$ & $\begin{array}{l}0.00 \\
(0.00)\end{array}$ & $\begin{array}{l}-0.73 \\
(0.44)\end{array}$ & $\begin{array}{l}0.00 \\
(0.00)\end{array}$ \\
\hline$G D P_{i t}$ & & $\begin{array}{l}0.48 \\
(3.00)\end{array}$ & & $\begin{array}{l}1.12 \\
(3.23)\end{array}$ & & $\begin{array}{l}0.85 \\
(3.52)\end{array}$ \\
\hline$G D P_{j t}$ & & $\begin{array}{l}-2.27^{*} \\
(1.06)\end{array}$ & & $\begin{array}{l}-1.89^{* *} \\
(0.69)\end{array}$ & & $\begin{array}{l}-1.49 \\
(1.02)\end{array}$ \\
\hline$G D P C A P_{i t}$ & & $\begin{array}{l}-1.52 \\
(3.94)\end{array}$ & & $\begin{array}{l}-1.93 \\
(3.83)\end{array}$ & & $\begin{array}{l}-2.71 \\
(4.64)\end{array}$ \\
\hline$G D P C A P_{j t}$ & & $\begin{array}{l}2.09^{*} \\
(1.07)\end{array}$ & & $\begin{array}{l}2.19^{* * *} \\
(0.69)\end{array}$ & & $\begin{array}{l}1.54 \\
(1.08)\end{array}$ \\
\hline$T R A D E_{i j t}$ & & $\begin{array}{l}0.43^{* * *} \\
(0.10)\end{array}$ & & $\begin{array}{l}0.33^{* * *} \\
(0.09)\end{array}$ & & $\begin{array}{l}0.42^{* * *} \\
(0.08)\end{array}$ \\
\hline$F R E N C H L A W_{j t}$ & & $\begin{array}{l}-1.18 \\
(2.14)\end{array}$ & & $\begin{array}{l}2.23^{* * *} \\
(0.68)\end{array}$ & & $\begin{array}{l}-2.39 \\
(1.35)\end{array}$ \\
\hline$F R E N C H L A W_{i t}$ & & $\begin{array}{l}-0.74 \\
(7.63)\end{array}$ & & $\begin{array}{l}0.67 \\
(8.19)\end{array}$ & & $\begin{array}{l}0.00 \\
(0.00)\end{array}$ \\
\hline$B O R D E R_{i j}$ & & $\begin{array}{l}1.36^{* * *} \\
(0.27)\end{array}$ & & $\begin{array}{l}1.18^{*} \\
(0.66)\end{array}$ & & $\begin{array}{l}0.00 \\
(0.00)\end{array}$ \\
\hline$I S L A N D_{j}$ & & $\begin{array}{l}-5.85 \\
(3.77)\end{array}$ & & $\begin{array}{l}-9.20^{* * *} \\
(2.72)\end{array}$ & & $\begin{array}{l}-3.30 \\
(2.03)\end{array}$ \\
\hline$A R E A_{j}$ & & $\begin{array}{l}0.00 \\
(0.00)\end{array}$ & & $\begin{array}{l}-0.00 \\
(0.00)\end{array}$ & & $\begin{array}{l}0.00^{* *} \\
(0.00)\end{array}$ \\
\hline$G O V E R N A N C E_{j}$ & & $\begin{array}{l}1.50^{* *} \\
(0.57)\end{array}$ & & $\begin{array}{l}1.96^{* * *} \\
(0.50)\end{array}$ & & $\begin{array}{l}-0.43 \\
(0.42)\end{array}$ \\
\hline$G O V E R N A N C E_{i}$ & & $\begin{array}{l}0.74 \\
(6.52)\end{array}$ & & $\begin{array}{l}2.34 \\
(7.02)\end{array}$ & & $\begin{array}{l}0.00 \\
(0.00)\end{array}$ \\
\hline$O F C_{j}$ & & $\begin{array}{l}-7.28^{*} \\
(3.86)\end{array}$ & & $\begin{array}{l}-9.23^{* * *} \\
(2.57)\end{array}$ & & $\begin{array}{l}-6.66^{*} \\
(3.23)\end{array}$ \\
\hline Observations & 3621 & 3302 & 6741 & 5911 & 3576 & 3315 \\
\hline R-squared & 0.80 & 0.83 & 0.72 & 0.75 & 0.79 & 0.81 \\
\hline
\end{tabular}

Note: Dependent Variable: $L_{i j t}$. Panel estimation by ordinary least squares with White's heteroskedasticity correction and clustering by creditor. See notes for tables 4, 5, and 6 for sample restrictions. Specifications include creditor country and time dummies, which are suppressed, along with conditioning variables COMLANG $G_{i j}, I S L A N D_{i}, A R E A_{i}, L A N D L O C K E D_{i}, L A N D L O C K E D_{j}, O F C_{i}, T_{A X H A V E N}$, $T A X H A V E N_{j}$. Estimates for suppressed variables available on request. Variables measured in dollars reported in logs. ${ }^{* * *}$ significant at 1 percent confidence level. ${ }^{* *}$ significant at 5 percent confidence level. $*$ significant at 10 percent confidence level. 
Table 9: Test for interactive EMU effect

\begin{tabular}{|c|c|c|c|c|}
\hline 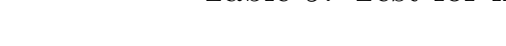 & (1) & $(2)$ & (3) & (4) \\
\hline Constant & $\begin{array}{c}23.56^{* * * *} \\
(1.85)\end{array}$ & $\begin{array}{c}65.22 \\
(63.38)\end{array}$ & $\begin{array}{c}59.82 \\
(56.91)\end{array}$ & $\begin{array}{c}48.86 \\
(67.50)\end{array}$ \\
\hline$E M U_{i j t}^{\text {pair }}$ & $\begin{array}{c}7.91^{* * *} \\
(2.11)\end{array}$ & $\begin{array}{l}-62.90 \\
(69.18)\end{array}$ & $\begin{array}{l}-40.58 \\
(61.22)\end{array}$ & $\begin{array}{c}-192.67 \\
(183.36)\end{array}$ \\
\hline$E M U_{i j t}^{\text {pair }} \times D I S T_{i j}$ & $\begin{array}{c}-0.97^{* * *} \\
(0.33)\end{array}$ & $\begin{array}{l}-0.44^{*} \\
(0.24)\end{array}$ & $\begin{array}{l}-0.35 \\
(0.34)\end{array}$ & $\begin{array}{l}-0.33 \\
(0.37)\end{array}$ \\
\hline$E M U_{i j t}^{p a i r} \times G D P_{j t}$ & & $\begin{array}{c}4.11 \\
(4.39)\end{array}$ & $\begin{array}{c}2.69 \\
(3.84)\end{array}$ & $\begin{array}{c}12.08 \\
(11.27)\end{array}$ \\
\hline$E M U_{i j t}^{\text {pair }} \times G D P C A P_{j t}$ & & $\begin{array}{l}-4.99 \\
(4.58)\end{array}$ & $\begin{array}{l}-3.52 \\
(3.91)\end{array}$ & $\begin{array}{l}-12.99 \\
(11.34)\end{array}$ \\
\hline$E M U_{i j t}^{\text {pair }} \times T R A D E_{i j t}$ & & $\begin{array}{c}0.41^{* * *} \\
(0.11)\end{array}$ & $\begin{array}{c}0.40^{* * *} \\
(0.12)\end{array}$ & $\begin{array}{c}0.39 * * * \\
(0.12)\end{array}$ \\
\hline$E M U_{i j t}^{\text {pair }} \times B O R D E R_{i j}$ & & & $\begin{array}{l}-0.30 \\
(0.70)\end{array}$ & $\begin{array}{l}-0.29 \\
(0.72)\end{array}$ \\
\hline$E M U_{i j t}^{\text {pair }} \times I S L A N D_{j}$ & & & $\begin{array}{c}0.00 \\
(0.00)\end{array}$ & $\begin{array}{c}0.00 \\
(0.00)\end{array}$ \\
\hline$E M U_{i j t}^{p a i r} \times G O V E R N A N C E_{j}$ & & & & $\begin{array}{c}0.88 \\
(0.81)\end{array}$ \\
\hline$D I S T_{i j}$ & $\begin{array}{c}-0.83^{* * *} \\
(0.21)\end{array}$ & $\begin{array}{c}-0.45^{* *} \\
(0.21)\end{array}$ & $\begin{array}{c}-0.40^{*} \\
(0.21)\end{array}$ & $\begin{array}{l}-0.40^{*} \\
(0.21)\end{array}$ \\
\hline$G D P_{j t}$ & & $\begin{array}{c}-2.42^{* *} \\
(1.05)\end{array}$ & $\begin{array}{c}-2.40^{* *} \\
(1.05)\end{array}$ & $\begin{array}{c}-2.37^{* *} \\
(1.05)\end{array}$ \\
\hline$T R A D E_{i j t}$ & & $\begin{array}{c}0.42^{* * *} \\
(0.10)\end{array}$ & $\begin{array}{c}0.42^{* * *} \\
(0.10)\end{array}$ & $\begin{array}{c}0.42^{* * *} \\
(0.10)\end{array}$ \\
\hline$B O R D E R_{i j}$ & & & $\begin{array}{c}1.10^{* * *} \\
(0.26)\end{array}$ & $\begin{array}{c}1.11^{* * *} \\
(0.26)\end{array}$ \\
\hline$I S L A N D_{j}$ & & & $\begin{array}{c}-15.76^{*} \\
(7.87)\end{array}$ & $\begin{array}{c}2.43^{* * *} \\
(0.44)\end{array}$ \\
\hline$A R E A_{j}$ & & & $\begin{array}{c}0.00 \\
(0.00)\end{array}$ & $\begin{array}{c}0.00^{* * * *} \\
(0.00)\end{array}$ \\
\hline$G O V E R N A N C E_{j}$ & & & & $\begin{array}{c}1.25^{* * *} \\
(0.40)\end{array}$ \\
\hline$O F C_{j}$ & & & & $\begin{array}{c}-8.62^{* *} \\
(3.16)\end{array}$ \\
\hline Observations & 3621 & 3302 & 3302 & 3302 \\
\hline R-squared & 0.80 & 0.83 & 0.83 & 0.83 \\
\hline
\end{tabular}

Note: Dependent Variable: $L_{i j t}$. Panel estimation by ordinary least squares with White's heteroskedasticity correction and clustering by creditor. See notes for tables 4, 5, and 6 for sample restrictions. Specifications include creditor country and time dummies, which are suppressed, along with conditioning variables COMLANG ${ }_{i j}, I S L A N D_{i}, A R E A_{i}, L A N D L O C K E D_{i}, L A N D L O C K E D_{j}, O F C_{i}, T A X H A V E N_{i}$, $T A X H A V E N_{j}$. Estimates for suppressed variables available on request. Variables measured in dollars reported in logs. ${ }^{* * *}$ significant at 1 percent confidence level. ${ }^{* *}$ significant at 5 percent confidence level. $*$ significant at 10 percent confidence level. 
Table 10: Two observations per creditor-debtor pair

\begin{tabular}{|c|c|c|c|c|c|c|}
\hline & $(1)$ & $(2)$ & (3) & (4) & (5) & (6) \\
\hline CONSTANT & $\begin{array}{l}27.13^{* * *} \\
(1.94)\end{array}$ & $\begin{array}{l}18.73 \\
(14.71)\end{array}$ & $\begin{array}{l}25.62^{* * *} \\
(1.89)\end{array}$ & $\begin{array}{l}22.86^{*} \\
(12.97)\end{array}$ & $\begin{array}{l}22.94^{* * *} \\
(1.57)\end{array}$ & $\begin{array}{l}18.33 \\
(15.92)\end{array}$ \\
\hline$E M U_{i j t}^{p a i r}$ & $\begin{array}{l}1.63^{* * *} \\
(0.27)\end{array}$ & $\begin{array}{l}1.51^{* * *} \\
(0.37)\end{array}$ & & & & \\
\hline$E M U_{i t}^{c r e d}$ & & & $\begin{array}{l}0.56^{* *} \\
(0.20)\end{array}$ & $\begin{array}{l}0.50 \\
(0.31)\end{array}$ & & \\
\hline$E M U_{j t}^{b o r r}$ & & & & & $\begin{array}{l}0.42 \\
(0.31)\end{array}$ & $\begin{array}{l}0.51^{* *} \\
(0.15)\end{array}$ \\
\hline$D I S T_{i j}$ & $\begin{array}{l}-0.87^{* * *} \\
(0.24)\end{array}$ & $\begin{array}{l}-0.13 \\
(0.21)\end{array}$ & $\begin{array}{l}-1.01 * * * \\
(0.24)\end{array}$ & $\begin{array}{l}-0.32^{*} \\
(0.18)\end{array}$ & $\begin{array}{l}-0.67^{* *} \\
(0.19)\end{array}$ & $\begin{array}{l}0.02 \\
(0.18)\end{array}$ \\
\hline$E C_{i}$ & $\begin{array}{l}-2.27^{* * *} \\
(0.49)\end{array}$ & $\begin{array}{l}-2.31^{* * *} \\
(0.38)\end{array}$ & $\begin{array}{l}1.98^{* * *} \\
(0.20)\end{array}$ & $\begin{array}{l}1.65^{* * *} \\
(0.23)\end{array}$ & & \\
\hline$E C_{j}$ & $\begin{array}{l}0.00 \\
(0.00)\end{array}$ & $\begin{array}{l}0.00 \\
(0.00)\end{array}$ & & & $\begin{array}{l}-0.15 \\
(0.38)\end{array}$ & $\begin{array}{l}0.00 \\
(0.00)\end{array}$ \\
\hline$T R A D E_{i j t}$ & & $\begin{array}{l}0.65^{* * *} \\
(0.13)\end{array}$ & & $\begin{array}{l}0.49^{* * *} \\
(0.09)\end{array}$ & & $\begin{array}{l}0.65^{* * *} \\
(0.11)\end{array}$ \\
\hline$B O R D E R_{i j}$ & & $\begin{array}{l}1.48^{* * *} \\
(0.37)\end{array}$ & & $\begin{array}{l}1.26^{* *} \\
(0.55)\end{array}$ & & $\begin{array}{l}0.00 \\
(0.00)\end{array}$ \\
\hline$C O M L A N G_{i j}$ & & $\begin{array}{l}-0.43 \\
(0.30)\end{array}$ & & $\begin{array}{l}0.55 \\
(0.47)\end{array}$ & & $\begin{array}{l}-0.48 \\
(0.26)\end{array}$ \\
\hline$A R E A_{j}$ & & $\begin{array}{l}0.00 \\
(0.00)\end{array}$ & & $\begin{array}{l}0.00 \\
(0.00)\end{array}$ & & $\begin{array}{l}0.00 \\
(0.00)\end{array}$ \\
\hline$L A N D L O C K E D_{j}$ & & $\begin{array}{l}0.00 \\
(0.00)\end{array}$ & & $\begin{array}{l}0.00 \\
(0.00)\end{array}$ & & $\begin{array}{l}0.00 \\
(0.00)\end{array}$ \\
\hline$I S L A N D_{j}$ & & $\begin{array}{l}-1.26 \\
(1.34)\end{array}$ & & $\begin{array}{l}-3.29^{*} \\
(1.68)\end{array}$ & & $\begin{array}{l}-0.24 \\
(1.40)\end{array}$ \\
\hline$T A X H A V E N_{j}$ & & $\begin{array}{l}0.00 \\
(0.00)\end{array}$ & & $\begin{array}{l}0.00 \\
(0.00)\end{array}$ & & $\begin{array}{l}0.00 \\
(0.00)\end{array}$ \\
\hline$C O M M O N L A W_{j t}$ & & $\begin{array}{l}0.00 \\
(0.00)\end{array}$ & & $\begin{array}{l}0.00 \\
(0.00)\end{array}$ & & $\begin{array}{l}0.00 \\
(0.00)\end{array}$ \\
\hline$F R E N C H L A W_{j t}$ & & $\begin{array}{l}0.67 \\
(0.69)\end{array}$ & & $\begin{array}{l}1.15^{* *} \\
(0.41)\end{array}$ & & $\begin{array}{l}-0.78 \\
(0.88)\end{array}$ \\
\hline$G O V E R N A N C E_{j}$ & & $\begin{array}{l}0.58 \\
(0.46)\end{array}$ & & $\begin{array}{l}0.96^{* *} \\
(0.38)\end{array}$ & & $\begin{array}{l}-0.38 \\
(0.25)\end{array}$ \\
\hline$O F C_{j}$ & & $\begin{array}{l}-2.69^{*} \\
(1.36)\end{array}$ & & $\begin{array}{l}-3.74^{* *} \\
(1.73)\end{array}$ & & $\begin{array}{l}-2.90 \\
(1.96)\end{array}$ \\
\hline$G D P_{j t}$ & & $\begin{array}{l}-0.41 \\
(0.54)\end{array}$ & & $\begin{array}{l}-0.44 \\
(0.43)\end{array}$ & & $\begin{array}{l}-0.39 \\
(0.55)\end{array}$ \\
\hline Observations & 196 & 187 & 371 & 355 & 196 & 189 \\
\hline R-squared & 0.88 & 0.90 & 0.80 & 0.84 & 0.86 & 0.89 \\
\hline
\end{tabular}

Note: Dependent Variable: $L_{i j t}$. Panel estimation by ordinary least squares with White's heteroskedasticity correction and clustering by creditor. Samples collapsed into one observation per borrower-creditor pair before and after EMU accession. Specifications include creditor country and time dummies, which are suppressed, along with conditioning variables $C O M L A N G_{i j}, I S L A N D_{i}, A R E A_{i}, L A N D L O C K E D_{i}$, $L A N D L O C K E D_{j}, O F C_{i}, T A X H A V E N_{i}, T A X H A V E N_{j}$. Estimates for suppressed variables available on request. Variables measured in dollars reported in logs. ${ }^{* * *}$ significant at 1 percent confidence level. ${ }^{* *}$ significant at 5 percent confidence level. ${ }^{*}$ significant at 10 percent confidence level. 